$25 / 112178$

A'NL-7 $7-16$

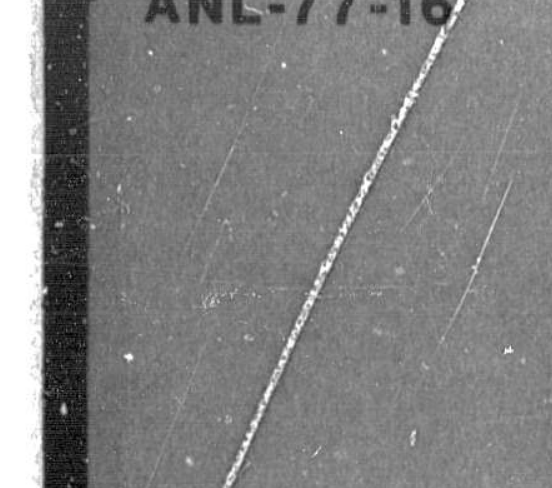

FL

FLUIDIZED-BED REGENERATION OF SULFATED' DOLOMITE,

FROM A COAL-FIRED FBC PROCESS

BY REDUCTIVE DECOMPOSITION

by

John C. Montagna, Gerhærd J. Vogel,

Gregory W. Smith, and /lbert A. Jonke

9

y
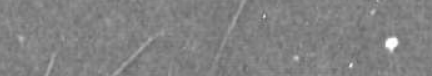

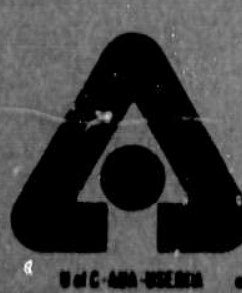

ARGONNE NATIONAL LABORATORY, ARGONNE, ILLINQIS

Proparod for the U. S. ENERGY RESEARCH AND DEVEYOPMENT ADMINISTRATION 

Distribution Category:

Coal Conversion and Utilization-Direct Combustica of Coal (UC-90e)

ANL $-77-16$

ARGONNE NATIONAL LABORATORY

9700 South Cass Avenue

Argonne, Illinois 60439

\section{FLUIDIZED-BED REGENERATION OF SULFATED DOLONITE FROM A COAL-FIRED FBC PROCESS \\ BY REDUCTIVE DECOMPOSITION}

by

John C. Montagna, Gerhard J. Vogel, Gregory W. Smith, and Albert A. Jonke

\section{Chemical Engineerinz Division}

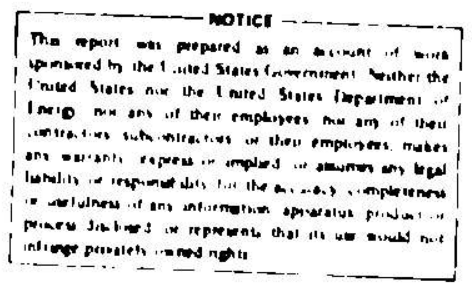

Apr 11191 

ABSTRACT . . . . . . . . . . . . . . . . . . . 1

SUMMARY. . . . . . . . . . . . . . . . . . . . . 1

INTRODUCTION . . . . . . . . . . . . . . . . . . . . 3

I. REGENERATION OF TYMOCHTEE DOLOMITE US ING METHANE

AS THE FUEL. . . . . . . . . . . . . . . . . . . . . 5

Experimental.................. 5

Results and Discussion. . . . . . . . . . . . 8

Ef fect of Fluldized-Bed Helght . . . . . . . . 11

Effect of Fluldizing-Gas Velocity. . . . . . . . . 11

Ef fect of Regeneration Temperature on

Regeneration and Resulfation of

Tymochtee Dolomite................ . 11

Electron Microprobe Analysis of Sulfated and Regenerated Particles.......... 15

Formation of $\mathrm{CaS}$. . . . . . . . . . . . 17

Attrition and Elutriation of Sorbent . . . . . . 19

Agglomeration of Sulfated Sorbent. . . . . . . 19

II. REGENERATION OF TYMOCHTEE DOLOMITE USING COAL

AS THE FUEL. . . . . . . . . . . . . . . . . . . 21

Experimental. . . . . . . . . . . . . . 21

Results and Discussion. ............... 23

Ef fect of Solids Residence Time and Temperature on Regeneration. . . . . . . . . . . . . 23

Regression Analysis of Regeneration Data....... 26

Analysis of Variance of Regeneration Data. . . . . . 28

Ef fect of Solids Residence Time and Temperature

on $\mathrm{SO}_{2}$ Concentration in the off-Gas. . . . . . . 28

Ef fect of System Pressure on Extent of $\mathrm{CaO}$

Regeneration and of $\mathrm{f}-\mathrm{Gas} \mathrm{SO}_{2}$ Concentrat ion ..... 31

Formation of $\mathrm{CaS}$. . . . . . . . . . . . 34

III. MASS AND ENERGY CONSTRAINED MODEL FOR THE REGENERATION PROCESS - 34

Model Description............... . . 34

Predicted Effects of Solids Residence TIme on

Volumetric Gas Change. . . . . . . . . . . . 38

Coal Feed Rate and Oxygen Concentration. . . . . . . 38

of $\mathrm{f}$-Gas Composition. . . . . . . . . . . . . . 38 
TARLE OF CONTENTS (Contd, )

Page

Heat Requírements. . . . . . . . . . . . . 38

Cost for Fuel Regeneration . . . . . . . . . . 38

Preliminary Sensitivity Analysis on Selected Process

Design Conditions . . . . . . . . . . . . . . . . . 38

IV. CONCLUSIONS. . . . . . . . . . . . . . . . . 46

ACKNOWLEDGMLNTS. . . . . . . . . . . . . . . . . . 4 46

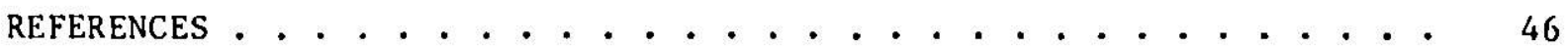




\section{LIST OF FIGURES}

No.

Title

$\underline{\text { Page }}$

1. Conceptual fluidized-bed coal combustion power-generating

facility having sorbent-regeneration and sulfur-recovery

capabilities. . . . . . . . . . . . . . . . . . . 4

2. Schematic diagram of the fluidized-bed regeneration system. . . 6

3. Schematic diagram of the regenerator reactor used for the experiments with $\mathrm{CH}_{1}$, and the expected axial oxygen concentration profile.......................

4. The effect of fluidizing-gas velocity on $\mathrm{CaO}$ regeneration

for sulfated Tymochtee dolomite . . . . . . . . . . . . . .

5. Effect of temperature on CaO regeneration for sulfated

Tymcchtee doiomite. . . . . . . . . . . . . . . . .

6. Pore distributions of dolomite samples fron. different process stages. . . . . . . . . . . . . . . . . . . . . .

7. Sulfation reaction data obtalned with a thermogravimetric analyzer at $900^{\circ} \mathrm{C}, 0.3 \% \mathrm{SO}_{2}$, and $5 \% \mathrm{O}_{2}$. . . . . . . . . .

8. Electron microprobe analyses of typical sulfated Tymochtee dolomite pirticles. . . . . . . . . . . . . . . . 16

E. Electron microprobe analysis of regenerated Tymochtee dolomite particles from Exp-1R2. . . . . . . . . . . . . . .

10. Electron microprobe analysis of regenerated Tymochtee dolomite particles from Exp-4. . . . . . . . . . . . . . . 18

11. Exp-1, fractional feed and product particle size distributions (upper graph). Attrition, characterized by the fractional product to feed mass ratios at different particle diameters (lower graph)..................... . . 20

12. Experimental sorbent regeneration system. . . . . . . . . 2 l

13. Schematic diagram of the regeneration reaction used for the experiments with coal and the expected axial oxygen concentration profile........................

14. Regeneration of CaO in Tymochtee dolomite as a function of solids residence timt . . . . . . . . . . . . . . . .

15. The extent of $\mathrm{CaO}$ regeneration for Tymochtee dolomite as a function of temperature and residence $t$ inie as represented by the model equation, Eq. $y$. . . . . . . . . . . . . . . 


\section{LIST OF FIGURES (Contd.)}

№.

Title

Page

16. Predicted and experimental $\mathrm{SO}_{2}$ concentration as a function of solids residence time at three regeneration temperatures

17. Predicted $\mathrm{SO}_{2}$ concentration in the dry of $\mathrm{f}-\mathrm{gas}$ as a function of solids residence time, regeneration temperature, and system pressure..................... 32

18. Flow diagram for the regeneration process mode1........ 35

19. Experimental solids regeneration and predicted increase in gas volume during regeneration as functions of solids residence time. . . . . . . . . . . . . . . . . .

20. Predicted and experimental required coal feed rate and oxygen concentration in the feed gas as functions of solids residence time. . . . . . . . . . . . . . . . .

21. Predicted off-gas constituent concentrations as functions of solids rosidence time. . . . . . . . . . . . . .

22. Predicted Incividual heat requirements as a function of solids residence $t$ ime . . . . . . . . . . . . . . . . .

23. Predicted fuel cost for regeneration per electric power unit produced when burning $3 \%$ sulfur coal as a function of solids residence time. . . . . . . . . . . . . . . . . . .

\section{LIST OF TABLES}

No.

Title

1. Design and experimental conditions, chemical analyses of regene rated products, and regeneration results. . . . . . . .

2. Rates and concentrations of the feed and effluent gases..... 10

3. lixperimental conditions and results for the regeneration of sulfated Tymuchtec dolomite by the incomplete combustion of Triangle coal in a fluldized hed. . . . . . . . . . . 24

4. Rates and concentrations of feed and effluent gases....... 25

5. Design condltions and inatrix representation for the $3^{2}$ factorlal experimental design . . . . . . . . . . . . 


$$
1: \text { OF TABLES (Contd.) }
$$

No.

6. Analysis of variance of extent of Cail regeneration data, CS series of experiments. . . . . . . . . . .

7. Effect of regeneration pressure on the regeneration of Tymochtee dolomite and the $\mathrm{SO}_{2}$ concentration in the off-gas...

8. Predicted effects of design conditions on regeneration results....................... 



\title{
FLUIDIZED-BED REGENERATION OF SULFATED DOLOMITE FROM A COAL-FIRED FBC PROCESS BY REDUCTIVE DECOMPOSITION
}

\author{
John C. Montagna, Gerhard J. Vogel, \\ Grigory W. Smith, and Albert A. Jonke
}

\section{ABSTRACT}

A fluidized-bed, reductive decomposition process has been developed for regenerating $\mathrm{CaSO}_{4}$, a product of fluidlzed-bed combustion. The effect of process operating varlables on the extint of regeneration and on $\mathrm{SO}_{2}$ levels in the of $f$-gas has been detirmined and a process model has been proposed.

\section{SUMMARY}

A process for regenerating spent $\mathrm{SO}_{2}$ sorbents has been developed on a PDU scale. Tymochtee dolomite that had been sulfated during fluidized-bed combustion of cnal is regenerated (reductive decomposition of $\mathrm{CaSO}_{4}$ to $\mathrm{CaO}$ and $\mathrm{SO}_{2}$ ) by the incomplete combust ion of either methane or coal in a fluidized-bed reactor.

In the first Investigation (methane was the fuel used), the effects of the operating viriables (temperature, fluldizing gas velocity, fluidized-bed height, solids residence time, and total reducing gas concentration in the eifluent) on the regeneration of $\mathrm{CaO}$ and on the bulldup of $\mathrm{CaS}$ were examined. It ars found that:

1. Deeper 'eds resultej in poorer regeneration because of unfavorable bed geonetry.

2. Increasing the fluldizing-gas velocity adversely affected regeneration.

3. Higher regeneration temperatures increased the extent and the rate of regeneration. However, dolomite that had been regenerated at a lower temperature was more reactive during subsequent sulfation.

4. In preliminary regeneration experiments, 5 to $15 \%$ of the sulfated dolomite (calcium basis) was lost, malnly by attrition. Solids residence $t$ ime ranged from 18 to $30 \mathrm{~min}$.

5. Electron microprobe analysis of the regenerated particles suggested a two-stage particle desulfurization mechanism. In the first stage, the sulfated core shrinks relatively rapidly (reaction $11 \mathrm{mited}$ ); in the second stage, the residual sulfur is removed more slowly (diffusion limited).

6. Concentrations of $\mathrm{SO}_{2}$ in the dry of $\mathrm{f}-\mathrm{gas}$ ranged from 0.8 to $7.3 \%$.

7. The extent of regeneration ranged from $21 \%$ to $89 \%$.

8. In experiments performed with $\sim 3 \%$ total reducing gas in the effluent, $\leq 0.1 \%$ sulfide was found in steady state regenerated dolomite samples; with $\sim 15 \%$ reducing gas in the effluent, sulfide concentrations in the products were of the order of $0.3-0.7 \%$. 
In the second investigation (coal was the fuel used), the effects of solids residence time $(7-35 \mathrm{~min})$, regeneration temperature $\left(1000-1100^{\circ} \mathrm{C}\right)$, and system pressure $(115-153 \mathrm{kPa})$ on (1) the extent of regeneration to $\mathrm{CaO}$ and (2) the $\mathrm{SO}_{2}$ concentration in the of $\mathrm{f}$-gas were investigated. The extent of regenerat 10 im improved at higher temperatures and longer solids residence times. A regeneration of $270 \%$ was accomplished at $1100^{\circ} \mathrm{C}$ with a solids residence time of $\sim 7 \mathrm{~min}$. The $\mathrm{SO}_{2}$ concentration in the dry of $\mathrm{f}-\mathrm{gas}$ increased at higher temperature (to $>10 \%$ in the dry of $\mathrm{f}-\mathrm{gas}$ at $1100^{\circ} \mathrm{C}$ ), at shorter solids residence time (bed weight/mass feed rate), and at lower pressure.

The results from these experiments were analyzed statistically, and an equation for the extent of $\mathrm{CaO}$ regeneration as a function of (1) sorbent residence time in the reactor and (2) regeneration temperature was obtained. This equation was used in the third section of this report in a mass and energy constrained model for the regeneration process, and a preliminary process sensitivity analysis has been performed. The fuel burden of sorbeut regeneration when a 3 wt \% S coal is burned in a power generation system has been estimated at $2-3 \%$. 
INTRODUCTION

The $\therefore$.... national goal, to become less dependent on forcign energy resources if . vily dependent on increased utllization of domestic highsulfur coai. $\because \%$ this end, fluldized-bed combustion of coal is currently being developed for electric power and/or steam generation. In the fluldized-bed coal combustion process, high-sulfur coal is combusted in a fluidized hed $\left(2900^{\circ} \mathrm{C}\right)$ of a sulfur-accepting sorbent. Natural calcium-based stones such as Ifmestones and dolomites are receiving primary consideration as sulfuraccepting sorbents (sulfur reacts with calcium to form $\mathrm{CaSO}_{4}$ ). The primary reasons are their acceptable reactivity, their low costs, and their bountful supply throughout the Unlted States.

Approximately one tonne of natural stone will be sulfated for every four tonnes of coal ( 23 kt $\% \mathrm{~S}$ ) combusted. In a $1000-\mathrm{MW}$ electrlc power plant ( $70 \%$ capacity factor), 22000 tonnes of stone per day will be sulfated. If the stone is used only once, this will generate large amounts of sulfated stone for disposal. Multicyclic utilization of the stones by regenerating the $\mathrm{CaO}$ is a potentially attractive alternative which would greatly reduce the quantity of solid waste that must be disposed of. Based on preserit dolomite or limestone cost, the feasibility of using a sorbent regeneration process in FBC power generation will depend on the cost of regeneration and on the environmental impact of the solid waste.

A conceptual power-generating facility utilizing fluidized-bed coal combustion and sorbent regeneration systems is schematically represented in Fig. 1. Steam is removed from the boller and is expanded in turbines to generate power. The flue gas (off-gas) from the boller meets EPA chemical emission requirements. After the sulfated sorbent is transferred to the regenerator and regenerated, this sorbent is combined with fresh sorbent (to conpensite for losses due to attrition and clianges in reactivity) and is recycled to the boller. The $\mathrm{SO}_{2}-\mathrm{rlch}$ of $\mathrm{f}-\mathrm{gas}$ from the regenerator is treated in a sulfur recovery plant.

For sulfur recovery, a process that uses coal as a reductant is recommended, such as the Foster-Wheeler RESOX process.' It is reconmended thit the off-gas from the sulfur recovery step be recycled to the boller and thus ellminate tall gas processing from the sulfur recuvery step. (The gats volume throughput in the regenerator is much smaller tron that in the boller.) An added advantage of this gas recycle is that any trace elements devolat 11 zed during regeneration of the sorbent would not be emitted to the atmosphere since trace elements would leave the regeneration system only in solid struams.

A sorbent regeneration process is being investigated in which $\mathrm{CaSO}_{4}$ is reductively decomposed in a fluidized bed at temperatures of $21100^{\circ} \mathrm{C}$. The heat and the reductants required are produced by incumplete combust ion of coal in the fluidized bed of sulfated stone. Two solid-gas reactions by which regeneration occurs are:

$$
\begin{aligned}
& \mathrm{CaSO}_{4}+\mathrm{CO} \rightarrow \mathrm{CaO}+\mathrm{CO}_{2}+\mathrm{SO}_{2} \\
& \mathrm{CaSO}_{4}+\mathrm{H}_{2} \rightarrow \mathrm{CaO}+\mathrm{H}_{2} \mathrm{O}+\mathrm{SO}_{2}
\end{aligned}
$$




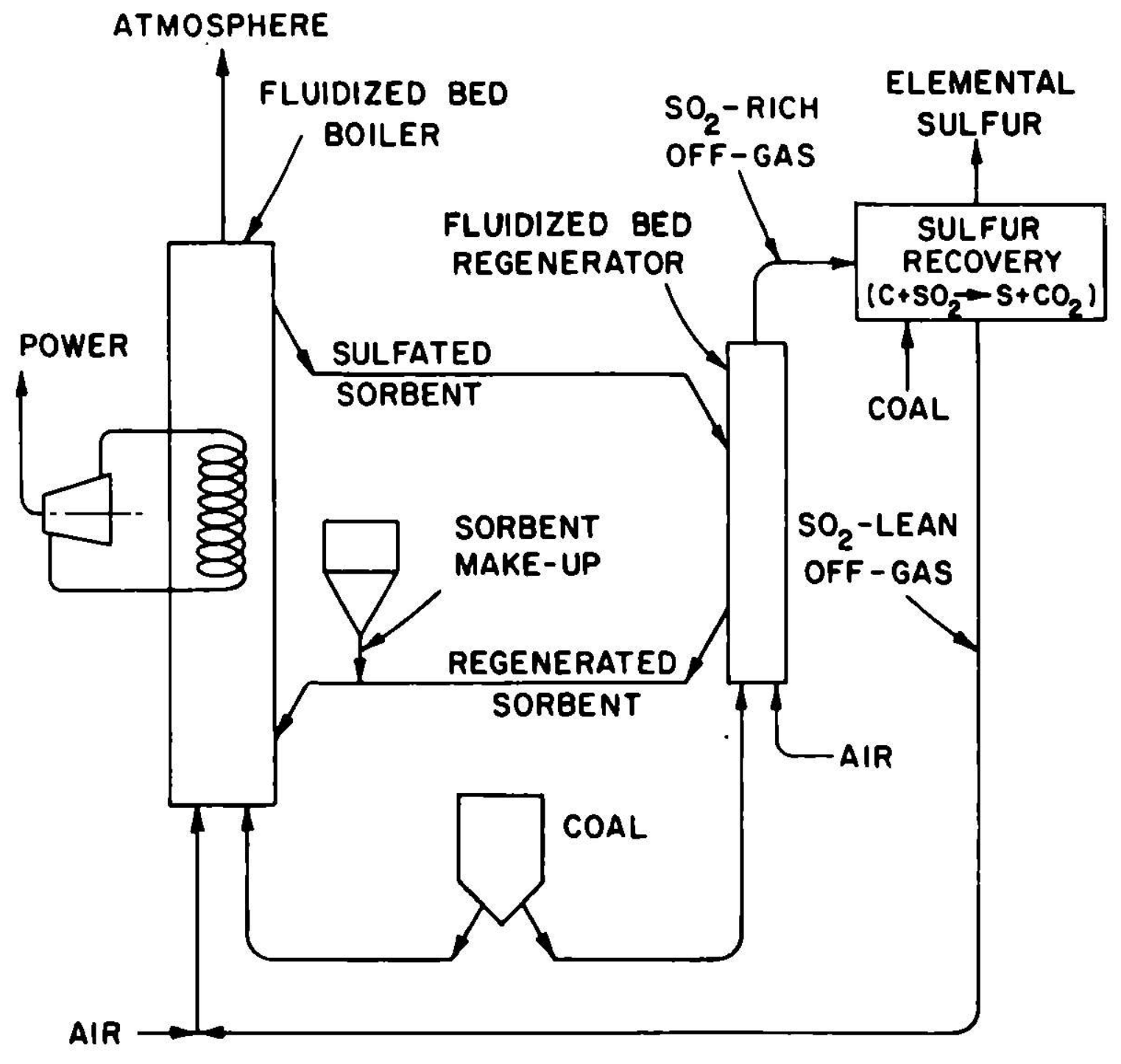

F1s. 1. Conceptual fluidized-bed coal combustion powergenerating facility having sorbent-regeneration and sulfur-recovery capabilities.

At lower temperatures and under more highly reducing conditions, the formation of CaS is favored:

$$
\begin{aligned}
& \mathrm{CaSO}_{4}+4 \mathrm{CO} \rightarrow \mathrm{CaS}+4 \mathrm{CO}_{2} \\
& \mathrm{CaSO}_{4}+4 \mathrm{H}_{2}+\mathrm{CaS}+4 \mathrm{H}_{2} \mathrm{O}
\end{aligned}
$$

When there is an oxidizing zone at the bottom of the flutdized bed (where the fluidizing gases, $O_{2}$ and $N_{2}$, are introduced), the listldup of Cals in minimized. The bulldup of large amounts of CaS 18 undesirable because it prevents

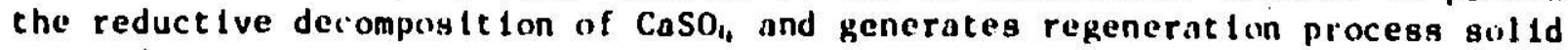
waste (ti.g., sollds collected from of $\mathrm{fgas}$ ) which cannot be diaposed of without further processing. ${ }^{2}$ 
The feasibllity of a sorbent reqeneration process will depend on (1) the ability to regenerate the stones and to generate an $\mathrm{SO}_{2}-\mathrm{rich}$ off-gas which can be treated in a sulfur recovery process, (2) the reactivity of the regenerated sorbent during subsequent sulfation (coal combustion) cycles, and ( 3 ) decrepitation of the sorbent at acceptable levels. A fresh sorbent makeup rate of $10-20 \%$ and an $\mathrm{SO}_{2}$. concentration in the of $\mathrm{f}$-gas of $8-10 \%$ appear to be technically feasible and economically acceptable. The requirements for a process have not yet been optimlzed; they will become better established as development work progresses.

The effects of key variables on the regeneration of $\mathrm{CaO}$ in Tymochtee. dolomite have been evaluated in two separate investigations. This report is arranged in four sections. The first section contains the results obtained in an early investigation in which methane was used os the fuel. The second section contains the results obtained in an investigation in which coal was used as the fuel. In the third section, a mass and energy constrained wodel for the regeneration process is given; it has been used to make a preliminary process sensitivity analysis. The fourth section contains the conclusions.

\section{REGENERATION OF TYMOCHTEE DOLOMITE US ING METHANE AS THE FUEL}

In the first investigation, both the heat and the required reducing gases for the regeneration reactions were generated by incomplete combustion of methane in a fluidized bed of partiall: sulfated dolomite. The effects of operating variables (temperature, fluidizing-gas velocity, fluidized-bed height, solids residence time, and total reducing gas concentration in the effluent gas) on the regeneration of $\mathrm{CaSO}_{4}$ to $\mathrm{CaO}$ and on the buildup of $\mathrm{CaS}$ were examined.

\section{Experimental}

The regeneration system (F1g. 2) consisted of a 7.62-cm-ID (3-in.-dia) fluidized-bed reactor (regenerator), a peripherally sealed rotary feeder for metering solids transported into the regenerator, and the of $f$-gas solidscleanup system. Another component was an electrically heated pipe heat exchanger used to preheat some of the fluldizing gas and for preheating air (used in startup only) to $2500^{\circ} \mathrm{C}$. The pressurized, fluidized-bed reactor was lined with a $6.35-\mathrm{cm}-\mathrm{th} 1 \mathrm{ck}$ castable refractory and encased in a $20.3-\mathrm{cm}$ (nominal 8-in.-dia) Schedule 40 pipe (Type 316 stainless steel), approximately $2.29 \mathrm{~m}(71 / 2 \mathrm{ft})$ long, with Its entire length contained within a $30.5 \mathrm{~cm}-\mathrm{d} l \mathrm{la}$ (nominal 12-1n.-dia) Schedule 20 carbon steel pipe. Different lal thermal expansion of the inner and outer pipes was accommodated by the use of packing glands on lines entering the bottom flange of the unit.

The experimental procedure consisted of first preheating the reactor and 1 t $\mathrm{B}$ bed of sulfated dolomite to $2430^{\circ} \mathrm{C}\left(800^{\circ} \mathrm{F}\right)$ with external wall heaters and preheated air. Kerosene was then combusted in the fluidized bed under oxidizing conditions to increase the temperature of the bed to $2870^{\circ} \mathrm{C}\left(1600^{\circ} \mathrm{F}\right)$, which is well above the auto-ignition temperature of methane. Methane was then fed in the place of kerosene and the fluidized bed was heated to $2982^{\circ} \mathrm{C}$ $\left(1800^{\circ} \mathrm{F}\right)$, at which temperature reducing conditions were establtshed. The 


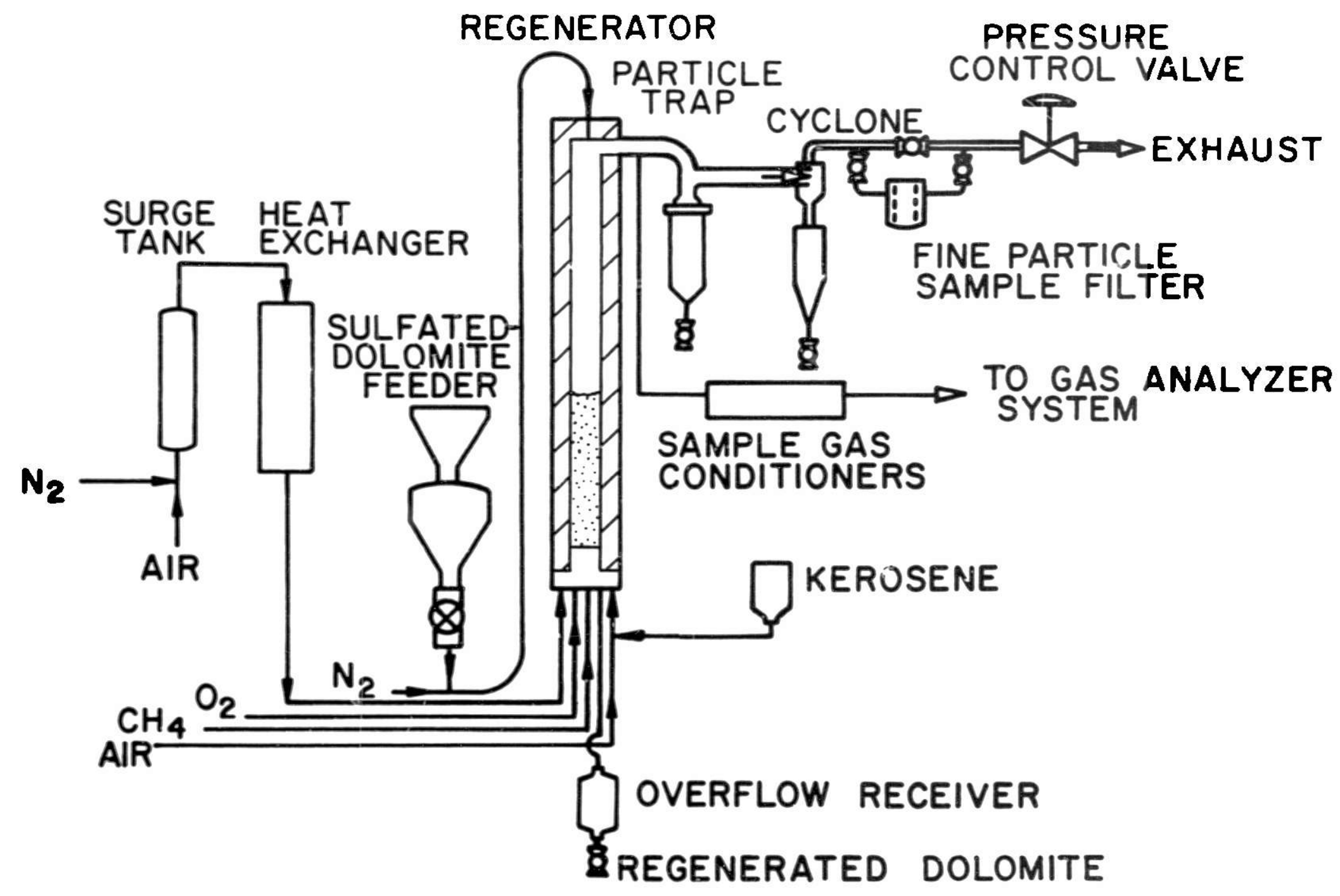

rig. 2. Schematic diagram of the fluidized-bed regeneration system. 
fluidizing gas was a mixture of nitrogen, oxygen, and methane. A multipoint injection system was used rather than a single injection point, to obtain lower local temperatures at the injection points. Oxygen and nitrogen were metered separately to produce the proper oxygen requirement in the reactor without changing the fluidizing-gas velocity. The final reducing conditions and operating temperature were approached slowly.

In this investigation, methane was combusted to generate both the heat and the reducing gases required for the reductive decomposition of $\mathrm{CaSO}_{4}$ in sulfated Tymochtee dolomite at $\sim 1010-1100^{\circ} \mathrm{C}$. The combustion reactions that dominate in the two zones of the fluidized bed are:

$$
\begin{array}{ll}
\text { Oxidizing Zone: } & \mathrm{CH}_{4}+2 \mathrm{O}_{2}+\mathrm{CO}_{2}+2 \mathrm{H}_{2} \mathrm{O} \\
\text { Reducing Zone: } & \mathrm{CH}_{4}+\mathrm{O}_{2}+\mathrm{CO}+\mathrm{H}_{2}+\mathrm{H}_{2} \mathrm{O}
\end{array}
$$

Excess methane served as a reductant as did $\mathrm{CO}$ and $\mathrm{H}_{2}$. Methane was infected Into the fluidized bed of the reactor through multiple infection points at locations beginning at $15 \mathrm{~cm}$ and ending at $25 \mathrm{~cm}$ above the gas distributor plate (F1g. 3). The location of methane infection was not varied throughout this investigation.

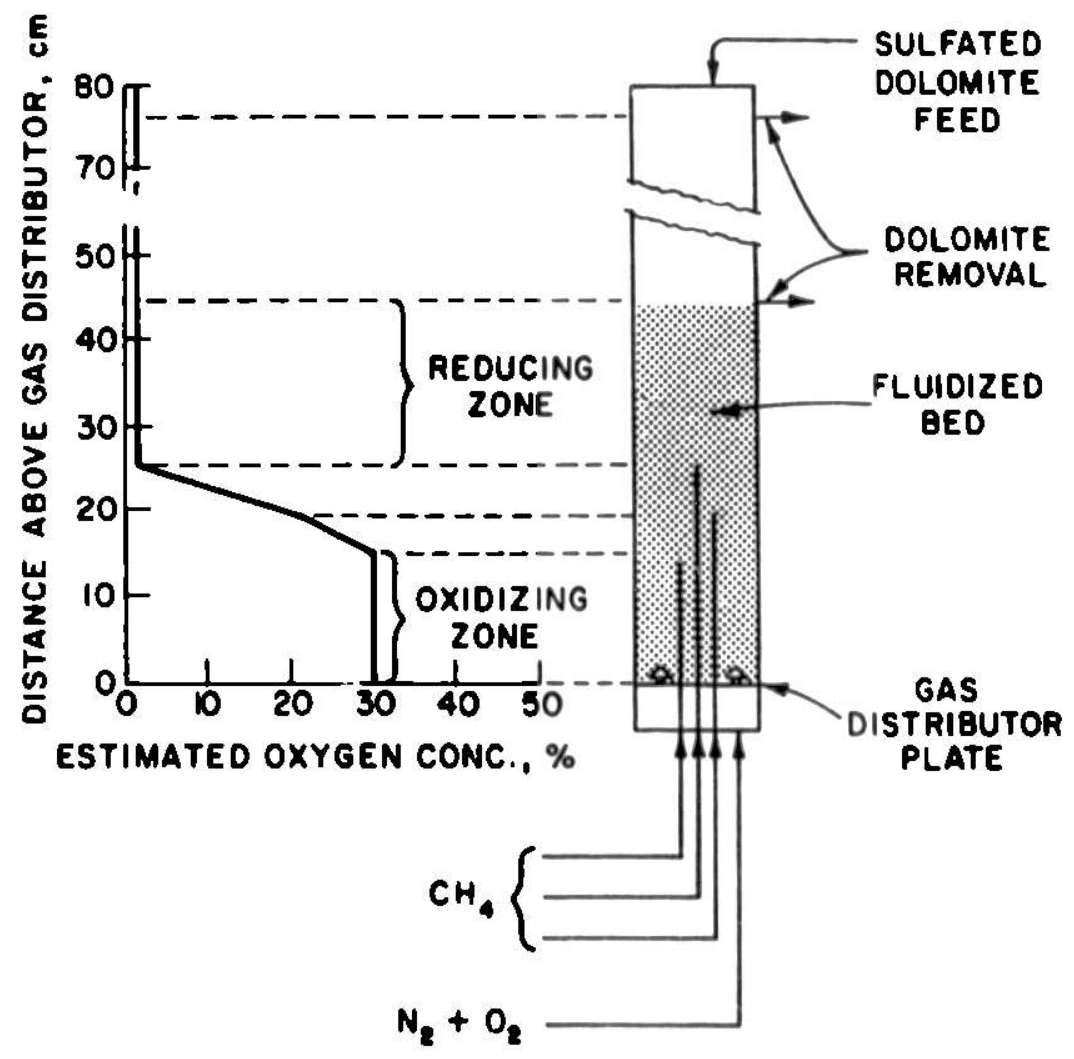

F1g. 3. Schematic diagram of the regeneration reactor used for the experiments with $\mathrm{CH}_{4}$ and the expected axial oxygen concentration profile. 
Sulfated dolomite was transported pneumatically from the storage hopper to the reactor and continually dropped onto the fluidized bed. Regenerated dolomite was continually removed from the bed through an overflow plpe. The fluidized-bed height was controlled by the location of the overflow pipe opening (see dolomite removal, Fig. 3) which was either $0.46 \mathrm{~m}$ or $0.76 \mathrm{~m}$ above the gas distributor. Solld samples taken over a $3 n-m i n$ steady state period were enalyzed by techniques having an accuracy of $25 \%$. Steady state was assumed to exist when (1) all of $f$-gas measurements were constant and (2) over $90 \%$ of the 1nitial bed material had been replaced (assuming backmixed solids flow).

In each experiment, a portion of the off-gas stream was continually removed, dewatered, and analyzed for $\mathrm{SO}_{2}, \mathrm{NO}, \mathrm{CH}_{4}, \mathrm{CO}$, and $\mathrm{O}_{2}$ : the gas was intermittently analyzed for $\mathrm{CO}_{2}$. In addition, steady state off-gas samples were analyzed for $\mathrm{H}_{2} \mathrm{~S}, \mathrm{H}_{2}$, and trace gases $\mathrm{COS}$ and $\mathrm{CS}_{2}$, using a mass spectrograph.

The Tymochtee dolomite that was regenerated contalned 10.2 wt $\% \mathrm{~S}$ as $\mathrm{CaSO}_{4}$ (none as $\mathrm{MgSO}_{4}$ ), $22.2 \mathrm{wt} \% \mathrm{Ca}$ and a nominal size distribution of -14 +45 mesh. In 1 ts virgin state, 1 t contained 50 wt $\% \mathrm{CaCO}_{3}$ and 39 wt $\%$ $\mathrm{MgCO}_{3}$. It was sulfated during the combustion of Arkwright (bituminous) coal which contalned 2.82 wt $\% \mathrm{~S}$. The methane fuel used during regeneration was tank pressurized $299 \% \mathrm{CH}_{4}$.

\section{Results and Discussion}

The percent regeneration of $\mathrm{CaO}$ was calculated from chemical analyses of the steady state products. It was based on the sulfur to calclum ratios In (1) the sulfated dolomite feed and (2) the steady state product after regeneration. These calculated regeneration percentages are compared in Table 1 with the percentages based on of $f$-gas analyses. The latter values are calculated from the ratios of the total sulfur released into the off-gas stream to the total sulfur contained in the sulfated dolomite feed. The gas volumetric changes in the fluidizing gas caused by the combustion and regeneration reactions were estimated. These estimates and the gas feed rate were used to calculate the of $f$-gas flow rate (see Table 2). The sulfur regeneration values obtained by chemical analysis of the regenerated products generally agreed, within analytical accuracy, with the values calculated from of $f$-gas analyses. The solids residence time was calculated as the ratio of the mass of the sorbent in the fluid bed to the feed rate of the sulfated sorbent.

The concentrations and rates of the feed and effluent gases are given in Table 2. Total reducing gas concentration is the sum of the concentrations of $\mathrm{CO}, \mathrm{H}_{2}$, and excess $\mathrm{CH}_{4}$ in the wet of $\mathrm{f}-\mathrm{gag}$. The concentrations of minor gas constituents, $\mathrm{CS}_{2}$ and $\cos$, In the of $-\mathrm{gas}$ ranged from 100 to $500 \mathrm{ppm}$. The water concentration in the of $f$-gas for these experiments, in which methane was combusted, was high. When other fuels (such as coal) having a lower hydrogen content are used for regeneration, the water content of the effluent gas is Jower. 
Table 1. Design and experimental conditions, chemical analyses of regenerated products, and regeneration results

Reactor ID, $7.62 \mathrm{~cm} \quad$ Pressure, $184 \mathrm{kPa}$

Additive, Sulfated Tymochtee dolomite (10.2 wt \% S)

\begin{tabular}{|c|c|c|c|c|c|c|c|c|c|c|}
\hline \multirow[b]{2}{*}{ Exp. } & \multicolumn{5}{|c|}{ Design Conditions } & \multirow[b]{2}{*}{$\begin{array}{c}\text { Fluidizing } \\
\text { Velocity, } \\
\text { m/sec }\end{array}$} & \multirow[b]{2}{*}{$\begin{array}{l}\text { Elutr. } \\
\text { Calcium } \\
\frac{\mathrm{x} 100}{\text { Feed }} \\
\begin{array}{c}\text { Calcium, } \\
\%\end{array}\end{array}$} & \multirow[b]{2}{*}{$\begin{array}{l}\text { Sulfide } \\
\left(\mathrm{S}^{2-}\right) \text { in } \\
\text { Regenerated } \\
\text { Products, } \\
\%\end{array}$} & \multirow[b]{2}{*}{$\begin{array}{l}\text { Measured } \\
\text { in } \mathrm{SO}_{2} \\
\text { Ef } 1 \text { luent, } \\
\% \text { dry }\end{array}$} & \multirow[b]{2}{*}{$\begin{array}{c}\mathrm{CaO} \\
\text { Regeneration, } \\
(\%)^{b} /(\%)^{c}\end{array}$} \\
\hline & $\underset{{ }^{\circ} \mathrm{C}}{\operatorname{Temp} .}$ & $\begin{array}{l}\text { Sorbent } \\
\text { Feed } \\
\text { Rate, } \\
\mathrm{kg} / \mathrm{hr}\end{array}$ & $\begin{array}{l}\text { Residence } \\
\text { Time, } \\
\text { min }\end{array}$ & $\begin{array}{l}\text { Bed } \\
\text { Height, } \\
\text { m }\end{array}$ & $\begin{array}{l}\text { Total } \\
\text { Reducing } \\
\text { Gas in } \\
\text { Effluent, } \\
\text { vol } \%\end{array}$ & & & & & \\
\hline 1 & 1040 & 2.72 & 30 & 0.46 & 3 & 0.67 & 5 & 0.1 & 4.0 & $70 / 76$ \\
\hline $\mathbf{I R I}$ & 1040 & 2.72 & 30 & 0.46 & 3 & 0.73 & 15 & $<0.1$ & 3.6 & $65 / 72$ \\
\hline iR2 & 1040 & 2.72 & 30 & 0.46 & 3 & 0.76 & 13 & $<0.1$ & 2.9 & $60 / 58$ \\
\hline 3 & 1040 & 4.54 & 18 & 0.46 & 15 & 0.79 & 12 & 0.3 & 5.7 & $70 / 79$ \\
\hline 4 & 1095 & 4.54 & 18 & 0.46 & 3 & 0.76 & 9 & $<0.1$ & 7.3 & $83 / 89$ \\
\hline 5 & 1040 & 4.54 & 30 & 0.76 & 15 & 0.82 & -- & 0.7 & 4.4 & $61 / 79$ \\
\hline $9 A$ & 1040 & 2.72 & 30 & 0.46 & 3 & 0.91 & -- & $<0.1$ & 1.5 & $40 / 40$ \\
\hline 7 & 1040 & 4.54 & 30 & 0.76 & 3 & 0.76 & 15 & $<0.1$ & 3.3 & $43 / 36$ \\
\hline 8 & 1010 & 272 & 30 & 0.46 & 3 & 0.70 & 14 & $<0.1$ & 0.78 & $15 / 21$ \\
\hline $9^{d}$ & 1040 & 2.72 & 30 & 0.46 & 3 & 0.76 & 11 & $<0.1$ & 1.7 & $58 / 55$ \\
\hline
\end{tabular}

anly elutriated particles larger than $15 \mathrm{~km}$ were monitored.

based on flue gas analysis.

CBased on chemical analysis of regenerated dolomite samples.

The feed was sulfated dolomite that had previously been partially regenerated

$(25.8$ wt $\% \mathrm{~S})$ in FAC-1 and FAC-1R1. 
Table 2. Rates and concentrations of the feed and effluent gases.

\begin{tabular}{|c|c|c|c|c|c|c|c|c|c|c|c|c|c|c|}
\hline \multirow[b]{2}{*}{ Exp. } & \multicolumn{5}{|c|}{ Feed Gas } & \multicolumn{9}{|c|}{ Effluent Gas (wet) } \\
\hline & $\begin{array}{l}\text { Rate, } \\
\text { i/min }\end{array}$ & $\underline{N}_{2}$ & $\frac{\mathrm{O}_{2}}{\%}$ & $\mathrm{CH}_{4}$ & $\overline{\mathrm{O}_{2} / \mathrm{CH}_{4}}$ & $\begin{array}{l}\text { Rate, } \\
\text { L/min }\end{array}$ & $\mathrm{CH}_{4}$ & CO & $\mathrm{H}_{2}$ & $\mathrm{O}_{\%}$ & $\mathrm{SO}_{2}$ & $\mathrm{H}_{2} \mathrm{~S}$ & $\mathrm{CO}_{2}$ & $\mathrm{H}_{2} \mathrm{O}$ \\
\hline 1 & 75.9 & 51.8 & 31.4 & 16.8 & 1.9 & 82.4 & 1.7 & 0.8 & 0.6 & 0.3 & 3.0 & $<0.07$ & 16 & 25 \\
\hline IRI & 81.4 & 57.8 & 27.7 & 14.5 & 1.9 & 87.7 & 1.7 & 0.5 & 0.6 & 0.1 & 2.6 & 0.02 & 16 & 27 \\
\hline 1R2 & 85.5 & 58.7 & 26.7 & 14.6 & 1.8 & 91.0 & 1.9 & 0.4 & 0.6 & 0.1 & 2.3 & 0.02 & 15 & 22 \\
\hline 3 & 88.2 & 42.4 & 33.3 & 24.3 & 1.4 & 100.5 & 11 & 1.7 & 1.5 & 0.06 & 4.1 & 0.6 & 20 & 28 \\
\hline 4 & 80.7 & 43.6 & 37.0 & 19.4 & 1.9 & 93.3 & 1.0 & 1.6 & 0.9 & 0.03 & 5.3 & 0.3 & 23 & 27 \\
\hline 5 & 90.8 & 42.5 & 33.9 & 23.6 & 1.4 & 104.4 & 10 & 1.7 & 1.4 & $\sim 0.2$ & 3.5 & 0.6 & 23 & 22 \\
\hline $9 \mathrm{~A}$ & 102.9 & 67.6 & 21.4 & 11.0 & 1.9 & 90.3 & 2.0 & 0.4 & 0.5 & 0.1 & 1.3 & 0.03 & 12 & 14 \\
\hline 7 & 93.6 & 49.0 & 33.8 & 17.2 & 2.0 & 83.6 & 1.7 & 0.3 & 0.3 & 0.1 & 2.7 & 0.03 & 20 & 20 \\
\hline 8 & 78.2 & 62.4 & 24.5 & 13.1 & 1.9 & 105.5 & 2.0 & 0.4 & 0.3 & 0.4 & 0.7 & $<0.04$ & 13 & 17 \\
\hline 9 & 83.0 & $6 \cap .5$ & 26.3 & 13.2 & 2.0 & 88.6 & 2.2 & 0.3 & 0.3 & 0.3 & 1.3 & 0.03 & 13 & 23 \\
\hline
\end{tabular}

at $101.3 \mathrm{kPa}$ and $22.8^{\circ} \mathrm{C}$. 
Effect of Fluidlzed-Bed Heighi. The bed height was varied by changing the height of the solids removal standpipe (see Fig. 3). This did not affect the height of the oxidiziug zone; only th reducing zone height in the fluid bed changed. The results of Exp-3 and Exp-5 (performed at the same sulfated dolomite feed rate, Table 1) were compared. It was found that increasing the nominal fluidized-bed helght from $0.46 \mathrm{~m}$ to $0.76 \mathrm{~m}$ (which increased the solids residence time from $18 \mathrm{~min}$ to $30 \mathrm{~min}$ ) did not improve the extent of $\mathrm{CaO}$ regeneration.

At a constant solids residence time ( $230 \mathrm{~min})$, increasing the fluidized bed height from $0.46 \mathrm{~m}$ (Exp-1R2) to $0.76 \mathrm{~m}$ (Exp-7) had a more pronounced effect on the extent of regeneration--decreasing it " $20 \%$.

The absence of a beneficlal effect of increased fluidized-bed height may have been due to the formation of larger gas bubbies in deeper beds causing more segregation if the gas phase from the well-fluidized phase, ispectally near the top of the bed. Transport of the reducing gases from the gas piase to the well-fluidized phase would become increasingly difficult; and this could reduce the extent of conversio. (the reactions are relatively fast). Also, poorer mixing in a deeper bed could prevent the sulfated dolomite from circulating throughout the entire bed, so that reaction would occur only in the upper, more segregated portion of thr fluldized bed (the feed solids were drupped on the top of the fluldized bed). This would result in the actual solids residence times in a deepe: bed being shorter than calculated.

Effect of Fluidizing-Gas Velocity. The effect of fluidizing-gas velocity on regeneration was evaluated by comparing the results of four experiments in which the sole variable was fluidizing-gas velocity (Fig. 4). As the gas velocity was increased from $0.67 \mathrm{~m} / \mathrm{sec}$ to $0.91 \mathrm{~m} / \mathrm{sec}$, CaO regeneration decreased from $76 \%$ to $40 \%$. In a study by Martin et al. ${ }^{3}$ on the reductive decomposition of gypsum in a $25.4-\mathrm{cm}-\mathrm{d}$ ia (10-in.-dia) fluidized bed, the opt Imum fluidizing-gas velocity (for decomposition) was found to be about $0.6 \mathrm{~m} / \mathrm{sec}$. However, the effect of fluldizing-gas velocity was reported to be small.

In this study, fluidizing-gas velocity had a meaningful effect in the investigated velocity range. The relatively small internal diameter $(7.62 \mathrm{~cm})$ of the fluldized-bed reactor probably enhanced the detrimental effect of gas velocity, lowering the fluidization quality.

At higher fluidizing-gas velocitles, the proportion of the gas in the bubbles in the fluldized bed Increased and the transport of gases from the bubble phase to the well-fluldized phase was hampered. Also, solids mixing was less effective at high fluidizing velocities because of the unfavorable bed geometry (a ratio of bed helght to bed diameter of 6 or 10).

Effect of Regeneration Temperature on Regeneration and Resulfat ion of Tymochtee Dolomite. The effect of regeneration temperature (ranging from 1010 to $1095^{\circ} \mathrm{C}$ ) on the regeneration of dolomite was evaluated in five experiments. The results are given in Fig. 5. In these five experiments, regeneration 


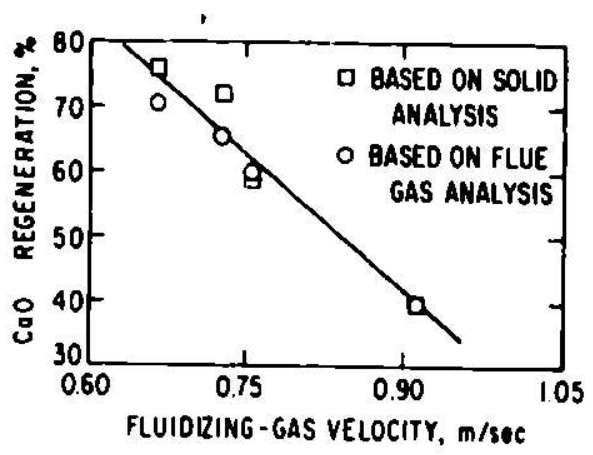

F1g. 4. The effect of fluidizing-gas velocity on $\mathrm{CaO}$ regeneration for sulfated Tymochtee dolomite.

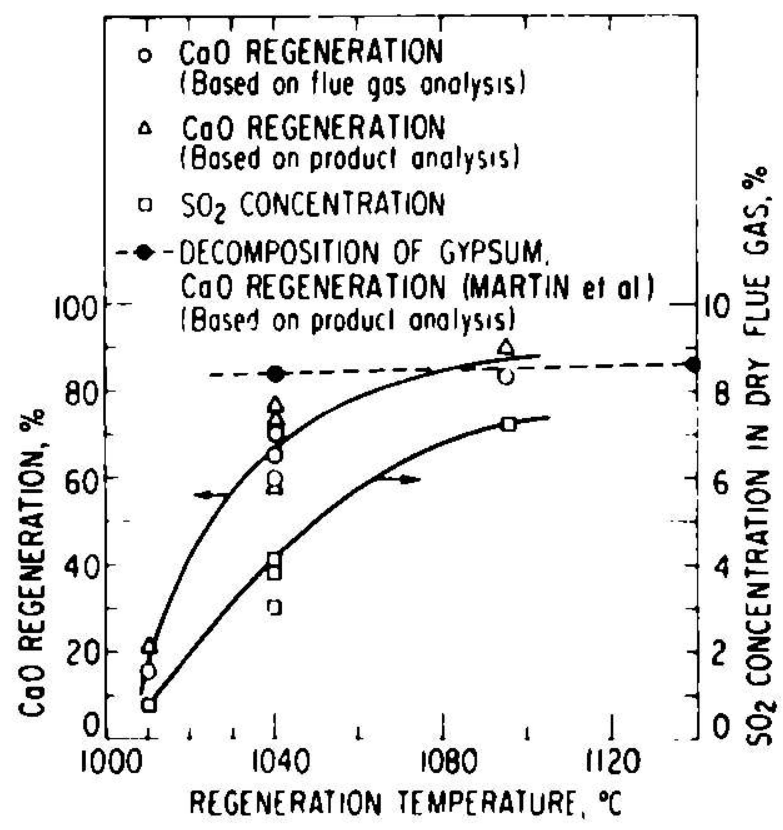

F1g. 5. Effect of temperature on $\mathrm{CaO}$ regeneration for sulfated Tymochtee dolontte. 
temperaturc was the only variable except that the solids residence time was $18 \mathrm{~min}$ instead of $30 \mathrm{~min}$ in the experiment at $1095^{\circ} \mathrm{C}$. As the temperature was increased from $1010^{\circ} \mathrm{C}$ to $1095^{\circ} \mathrm{C}$ and the solids residence time remained constant or decreased, $\mathrm{CaO}$ regeneration (based on analysis of the regenerated product) increased from $21 \%$ to $89 \%$, and the $\mathrm{SO}_{2}$ concentration in the dry $>1 \mathrm{f}-$ gas increased from $0.8 \%$ to $7.3 \%$.

The temperature dependence of the regeneration of sulfated Tymochtee dolomite in these experiments was compared (see Fig. 5) with similar results obtained by Martin et al. ${ }^{3}$ In that investigation, the reductive decomposition of gypsum was studied, with carbon the reductant in a $25.4-\mathrm{cm}-\mathrm{d}$ ia fluldized bed (solids residence time of $290 \mathrm{~min}$ ). The results agree at the higher temperature where the rate of decomposition $1 \mathrm{~s}$ fast and most of the conversion occurs in the first few minutes of the reaction.

Porosity measurements of samples $(-25+35$ mesh particles) at several process steps have been made $(\mathrm{F} 1 \mathrm{~g} .6)$ to evaluate the effect of regeneration temperature on the quality of the regenerated dolomite as a $\mathrm{SO}_{2}$-acceptor. Porosity was measured as the extent of penetration of mercury as a function of pressure. The cumulative pore volumes (mercury penetration) per $0.5 \mathrm{~g}$ of sorbent as a function of pore dlameter are glven (Fig. 6).

Curve A represents the pore size distribution of fully calcined virgin dolomite that was calcined at $900^{\circ} \mathrm{C}$ for $2 \mathrm{hr}$ in a furnace (preated to $900^{\circ} \mathrm{C}$ ) In a $20 \% \mathrm{CO}_{2}-80 \%$ air environment. The pore volume for pores $0.4 \mathrm{um}$ and 1 arger was found to be $0.1 \mathrm{~cm}^{3} / 0.5 \mathrm{~g}$. As reported by Hartman and Coughl in, ${ }^{4}$ most. sulfation takes place in the larger pores $(>0.4 \mu \mathrm{m})$. Pores smaller than $20.4 \mu \mathrm{m}$ are relatively easy to plug and therefore contribute $11 \mathrm{tt}$ le to the extent of sulfation. The pore distribution of fully calcined virgin dolomite was compared with that of sulfated and regenerated dolomite because dolomite is fully calcined during regeneration.

Curve B represents the prre volume distribution of dolomite that was sulfated ( 10.2 wt $\% \mathrm{~S}$ ) in coal combustion experiments at $900^{\circ} \mathrm{C}$; this sulfated dolomite was used as the feed for the regeneration experiments. The pore volume for pores $0.4 \mu \mathrm{m}$ and larger was found to be $0.045 \mathrm{~cm}^{3} / 0.5 \mathrm{~g}$. In contrast to the pore volume distribution of the calcined material, the pores of the sulfated materlal were severely plugged by sulfation. The pores shrink during sulfation of $\mathrm{CaO}$ as a result of changes in molecular volume.

Curves $C$ and $D$ 1llustrate the pore volume distribution of dolonite that was regenerated at $1040^{\circ} \mathrm{C}$ or $1095^{\circ} \mathrm{C}$. At the higher regeneration temperature, the volume of the larger pores $(>0.4 \mu \mathrm{m})$ was greater. On the basis of this result, the sulfation reactivity of dolonite regenerated at the higher temperature was expected to be greater.

Sulfation experiments with the regenerated samples and the calcined dolomite sample were performed in thermogravimetrlc analyzer. The results are given in Fig. 7. It was found that the higher regeneration temperature did not improve the reactivity of the dolomite with $\mathrm{SO}_{2}$. Rather, the dolomite that was regenerated at $1095^{\circ} \mathrm{C}$ was found to have a lower reactivity than the dolomite regenerated at $1040^{\circ} \mathrm{C}$ and the precalcined dolumite. 


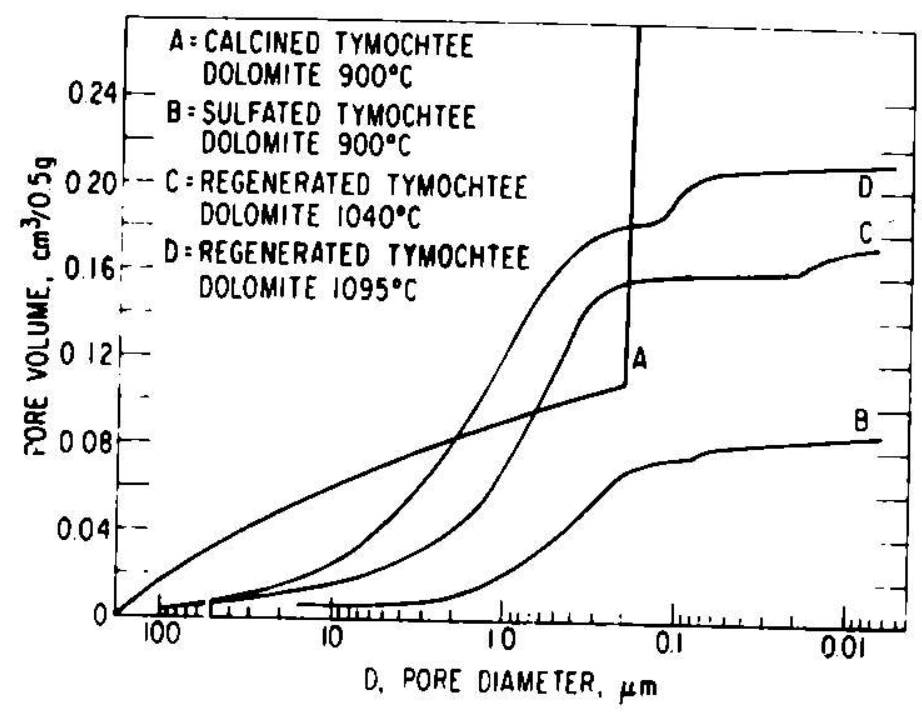
F1g. 6. Pore distributions of dolomite samples from
different process stages.

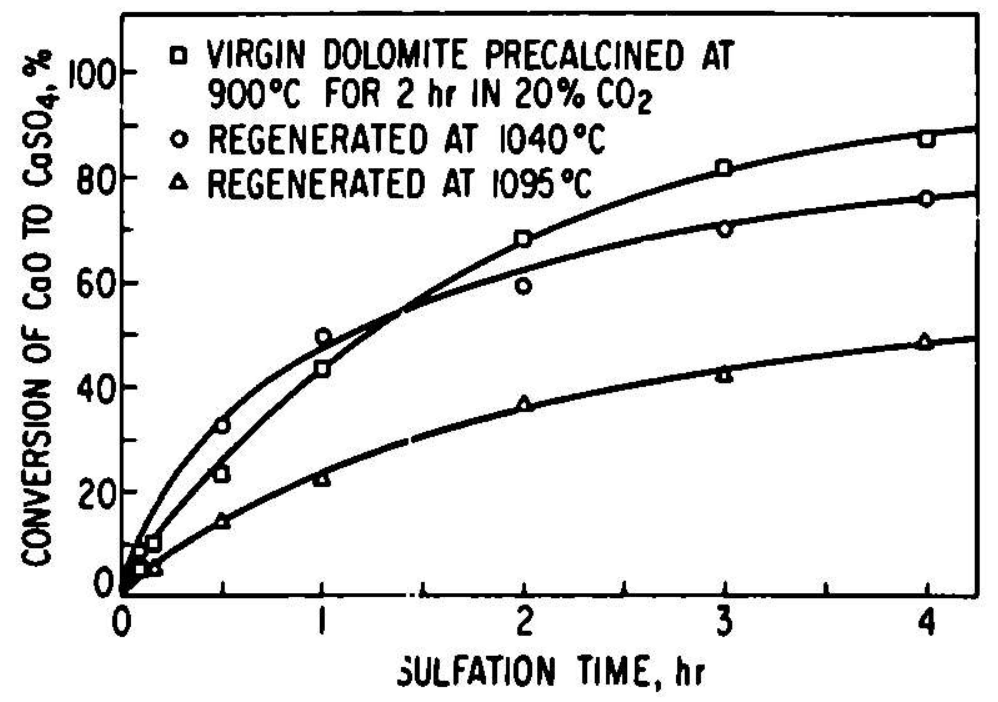

F1g. 7. Sulfation reaction data obtained with a thermogravimetric onalyzer at $900^{\circ} \mathrm{C}, 0.3 \overline{\mathrm{SO}_{2}}$, and $5 \%$ $\mathrm{O}_{2}$. 
Although higher regeneration reaction rates were obtained at the higher regeneration temperature, the potential detrimental effect of high regeneration temperatures on the reactivity of the dolomite in subsequent sulfatiun cycles requires further study. A decrease in the reactivity of regellerated sorbent during cyclic exposures to high temperature was reported by Skopp et $a l^{5}$ In that study, the reactivity loss was presumed to be caused by loss in porosity. In this study, the sorbent's porosity increased after one cycle in the second sulfation step.

Electron Microprobe Analysis of Sulfated and Regenerated Particles. Regenerated Tymochtee dolomite particles from some of these experiments (Exp-IR2 and 4), as well as nonregenerated sulfated Tymochtee dolomite particles, were analyzed with an electron microprobe to determine the effect of regeneration on the sulfur concentration profiles in individual particles. The radial distributions of calcium, magnesium, and sulfur were measured. A random sample of particles was screened; then approximately twenty nominally $-20+25$ mesh particles were mounted in epoxy and machined to remove the equivalent of one-half of the nominal diameter of a typical mounted particle $(\sim 400 \mu \mathrm{m})$. A thin gold layer ( 250 argstroms) was sputtered on the machined surface to enhance the conductivity of the mounts. Apatite ( $38.9 \mathrm{wt} \% \mathrm{Ca}$ ), $\mathrm{FeS}_{2}$ (53.4 wt \% S), and $\mathrm{MgO}(60.3 \mathrm{wt} \% \mathrm{Mg}$ ) were used as standards to cal1brate the probe and to obtain a rough quantitative estimate of the local component concentrations.

The radial concentration distributions of calcium and sulfur as obtained by the electron probe for three typical sulfated particles are given in Fig. 8 (magnesium concentration profiles are not given because they are similar to those for calcium). The extent of sulfation in these particles varied because the particles had been sulfated in the continuously fed, fluidlzed-bed coal combustor for different perlods of time (solids are backmixed). The extent of sulfation was least for the particle represented at the top of the figure and greatest for the bottom particle. As sulfation progressed, the edge of the sulfated shell moved towards the center of the particle. The local sulfur and calclum concentrations obtained were lower than the true local concentrations because irregularities on the surfaces caused scattering of the characteristic emitted X-rays (the sample surfaces could not be machined as smooth as the calibration sample surfaces). The bulk concentrations of sulfur and calclum, obtained by wet chemical analysis of the sample from which these particles were taken, were 10.2 wt $\%$ and 22.2 wt $\%$, respectively.

Regenerated particles from Exp-IR2 (performed at $1040^{\circ} \mathrm{C}$ ) were chemically analyzed and found to contain 5.1 wt $\% \mathrm{~S}$ and 26.2 wt $\% \mathrm{Ca}$. The electrun microprobe analyses of two sample particles from this experiment are given in Fig. 9. In the particle whose analysis is given at the top of Fig. 9, regeneration apparently was in an early stage, with the primary regeneration-reaction zone moving radially into the uniformly sulfated particle. Some residual sulfur (sulfur that is less accessible, probably due to diffusion limitation) is left behind the advancing primary reaction zone. The bulk. of the sulfur is removed during the first regeneration stage. The particle represented by the other electron probe analysis is in a later (slower) stage of regeneration and the residual concentration of sulfur in the entire particle is relatively low. 

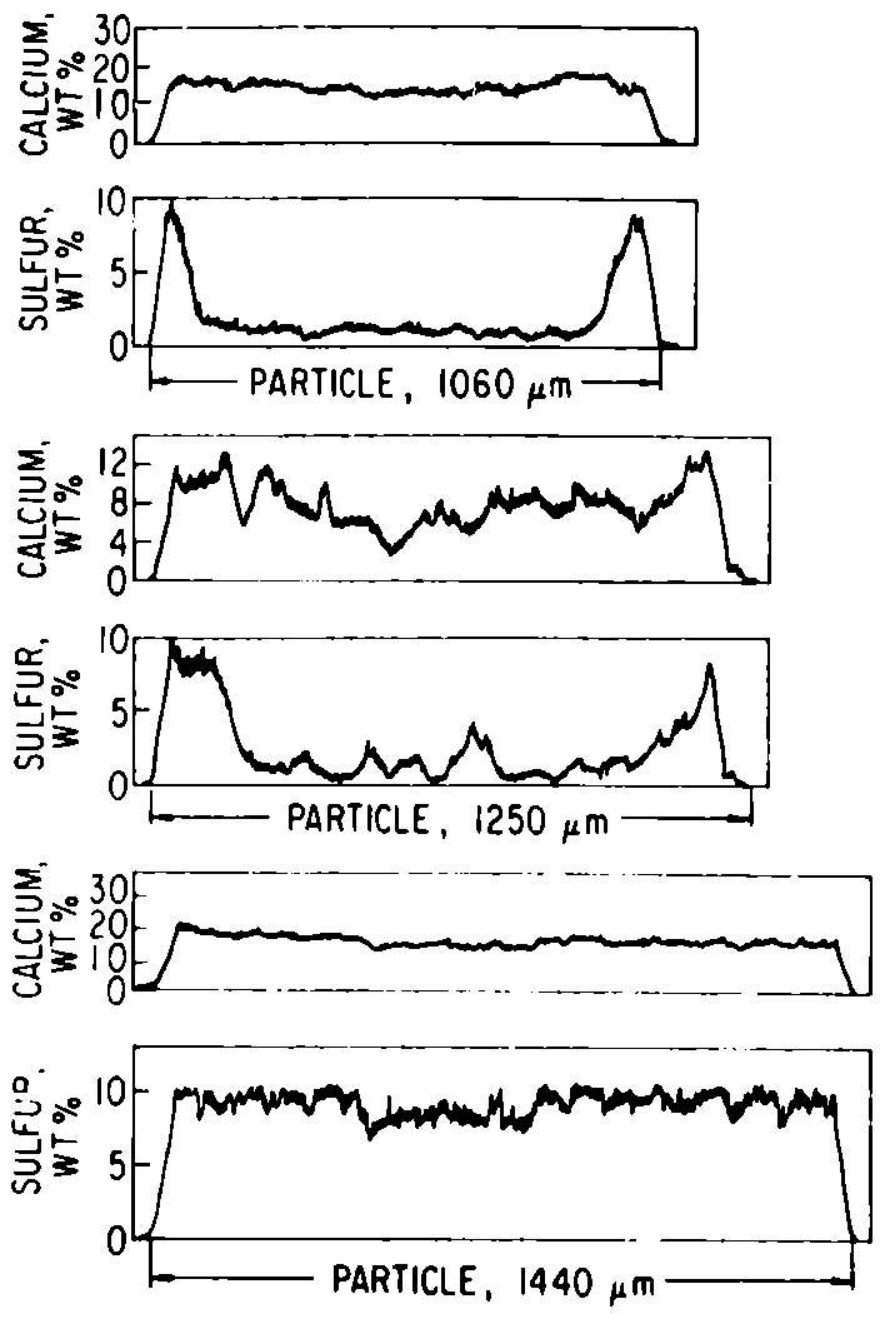

F18. 8. Electron microprobe analyses of typical sulfated Tymochtee dolomite particles.

(Note the difference in scales for the two diagrams.) In an industrial process In which the solids residence $t$ ime would be short (high solids throughput rate), probably only the f Irst (rapld) stage of regeneration would occur. Hence, most but not all of the sulfur would be removed in an industrial regeneration process.

Electron microprobe analyses were also performed on regencrated particles from Exp-4, which was conducted at the higher temperature of $1095^{\circ} \mathrm{C}$. The bulk calclum and sulfur concentrations in regellerated Tymochtee dolomite from this experiment were 30 wt $\chi$ and 1.5 wt $\chi$, respectively. The electron microprobe analyses for calcium and sulfur in three particles from this exper lment are shown in Fig. 10. The particle whose analysis is given at the top of 

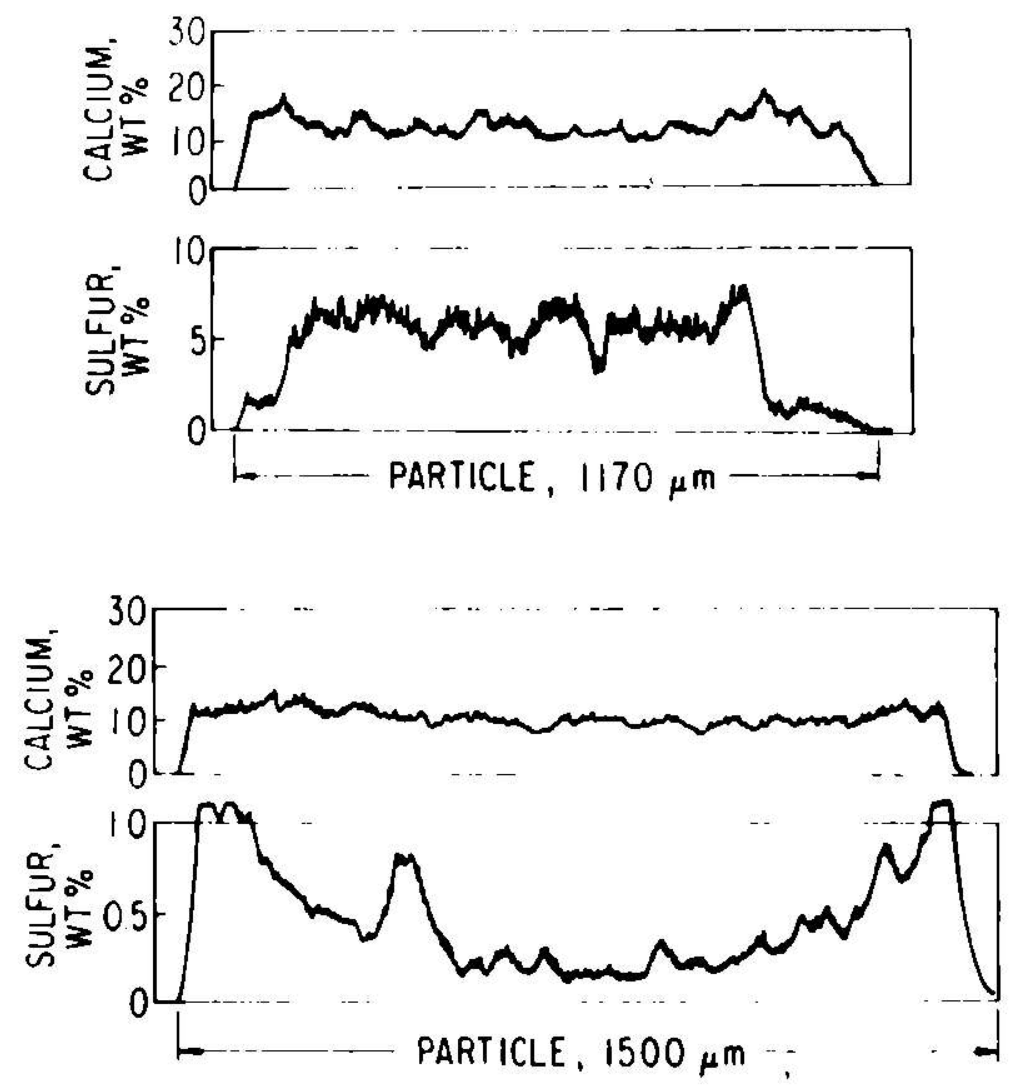

F1g. 9. Electron microprobe analysis of regenerated Tymochtee dolomite particles from Exp-IR2.

F1g. 10 appears to be near the end of the first regeneration atage; the primary desulfurization reaction zone has almost reached the center of the particle. Regeneration in the other two particles is more nearly complete. A greater extent of regeneration was observed in particles from Exp-4 than in particles from Exp-IR2 (regenerated at a lower temperature). Generally, the regenerated particles examined showed no sulfur concentration irregularities that might lead to poor Ut!llzation in subsequent sulfation cycles.

Formation of CaS. The buildup of large amounts of CaS would be detrimental to the reductive decomposition of $\mathrm{CaSO}_{1}$, to $\mathrm{CaO}$. The sulfide analysis of the regenerated products are given in Table 1 of the four vari bles in these experiments, only reducing gas concentration in the effluent gas had an effect of sulfide bulldup. Very small amounts of sulfide $(-0.1 \%)$ were found in the steady state regenerated dolomite samples from ali experiments performed with low reducing gas condit Ions (i.c., with $23 \%$ total reducing gas In the effluent). With $215 x$ reducing $8 a s$ in the effluent, the butldup of CaS was enhanced--for example, in two experiments, sulfide concentrations In the products were 0.3 and $0.7 \%$, respectively 

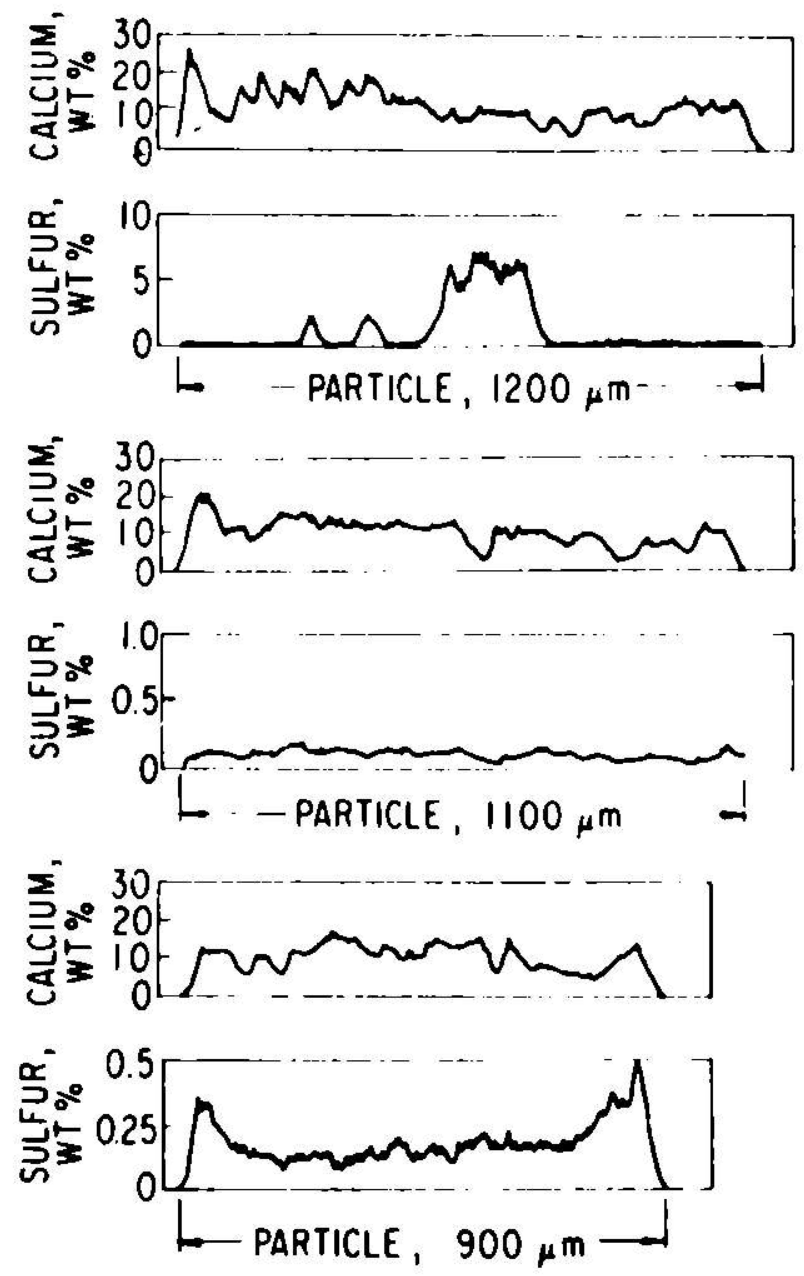

F1g. 10. Electron microprobe analysis of regenerated Tymochtee dolomite particles from Exp-4.

The obtained experimental sulfide concentrations are much lower than those predicted by the equilibrium equation (below) at the experimental of $f-g a s$ conditions of these experiments.

$$
1 / 4 \mathrm{CaSO}_{4}+\mathrm{CO} \rightarrow 1 / 4 \mathrm{CaS}+\mathrm{CO}_{2}, \frac{1}{\mathrm{k}_{\mathrm{p}}} \cdot \frac{\mathrm{P}_{\mathrm{CO}}}{\mathrm{P}_{\mathrm{CO}_{2}}}
$$

At $1040^{\circ} \mathrm{C}$, the maximum partial pressure ratio of $\mathrm{Co}$ to $\mathrm{CO}_{2}\left(\mathrm{P}_{\mathrm{Co}} / \mathrm{P}_{\mathrm{CO}}\right)$ for which $\mathrm{CaS}$ and $\mathrm{CaSO}_{4}$ coexigt is 0017 . At higher partial pressure ratiob, only CaS should exlst at equilibrium. " Since the experimental values of partial pressure rat 108 of $\mathrm{CO}$ to $\mathrm{CO}_{2}$ in the effluent for these experiments were all above 0.02 , higher sulfide concentrations $\mathrm{might}$ be expected. The experimental results may be explained on the basis that (1) the sorbent in the fluldizedbed reactor 18 not at equilibrium and (2) the conditlons in the fluidized bed are not reducing throughout (Bee $F 1 g .3$ ). The fluldizing gas $\left(N_{2}\right.$ and $\mathrm{O}_{2}$ ) was 
Introduced through the gas distributor, and a highly oxidizing zone was establ1shed (see Table 2) between the gas distributor and the methane injection ports, as illustrated in Fig. 3. A multipoint injection system was used; rather than a single injection point, to obtain lower local temperatures at the injection points. In the oxidizing zone, CaS was oxidized:

$$
\begin{gathered}
\mathrm{CaS}+2 \mathrm{O}_{2} \rightarrow \mathrm{CaSO}_{4_{4}} \\
\mathrm{CaS}+3 / 20_{?} \rightarrow \mathrm{CaO}+\mathrm{SO}_{2}
\end{gathered}
$$

A reducing zone was established in the top portion of the fluidized bed. Solid reactants and products are circulated between the reducing and oxidizing zones, allowing CaS to be oxidized to $\mathrm{CaSO}_{4}$ and this minimizes the buildup of $\mathrm{CaS}$.

In related experimental investigations by others, an oxidizing zone to oxidze the CaS was purposely created above the reducing zone by adding secondary air or oxygen near the top of the fluidized bed during the decomposition of gypsum ${ }^{7}$ and anhydrous $\mathrm{CaSO}_{4}$ and sulfated 11mestone. ${ }^{8}$

Attrition and Elutriation of Sorbent. Knowledge of the extent of attrition of sorbent is of major concern in the development of a sorbent regeneration process. The physical integrity of sorbent purticles may be affected by thermal stresses at the high process temperature $\left(41100^{\circ} \mathrm{C}\right)$ and by molecular rearrangements within the particles due to regeneration reactions.

Losses of regenerated dolomite due to attrition and/or elutriation (including attrition during pneumatic transport) at the various conditions used in these experiments were measured. Since the sulfated dolomite was nominally $-14+45$ mesh and the particles elutriated from the bed were all nominally -45 mesh $(<350 \mu \mathrm{m})$, it was assumed that the elutriated particles were attrited fragments of the feed Tymochtee dolomite. Table 1 shows the fraction of dolomite lost curing regeneration because of attrition and consequent elutrlation (elutriated calcium as a percentage of feed calcium). The loss ranged from $5-15 \%$.

Sorbent attrition was also characterlzed by a more direct approach; the fractional distributions of the sulfated feed and regenerated product for rxp-1 were plotted (Fig. 11, upper plot). The fractional distribution curves suggest a particle population shift to small dianeters in the regenerated dolomite. This was confirmed by plotting the mass ratios from Exp-1 (i.e.. the calcium mass content of the product to the calclum mass concent of the feed dolomite) as a function of particle diameter (Fig. 11, lower plot). Generally, all plots of fractional product-to-feed calciutin rat lo as a function of particle dlameter showed that during regeneration, the number of larger particles $(>800 \mathrm{um})$ decreased and the number of medfum-size particles $(\cdot 300$ and $<800 \mu \mathrm{m})$ increased because of attrition of the larger particles.

Agglomeracion of Sulfated Dolomite. Partial agglomeration of the sulfated dolomite bed occurred when a regeneration experiment was at tempted with a bed temperature of $1095^{\circ} \mathrm{C}$ and a $15 \%$ reducing gas concentration in the effluent gas. It is believed that insufficlent fluidization velocity at these conditions caused some particles to adhere to each other. This was 


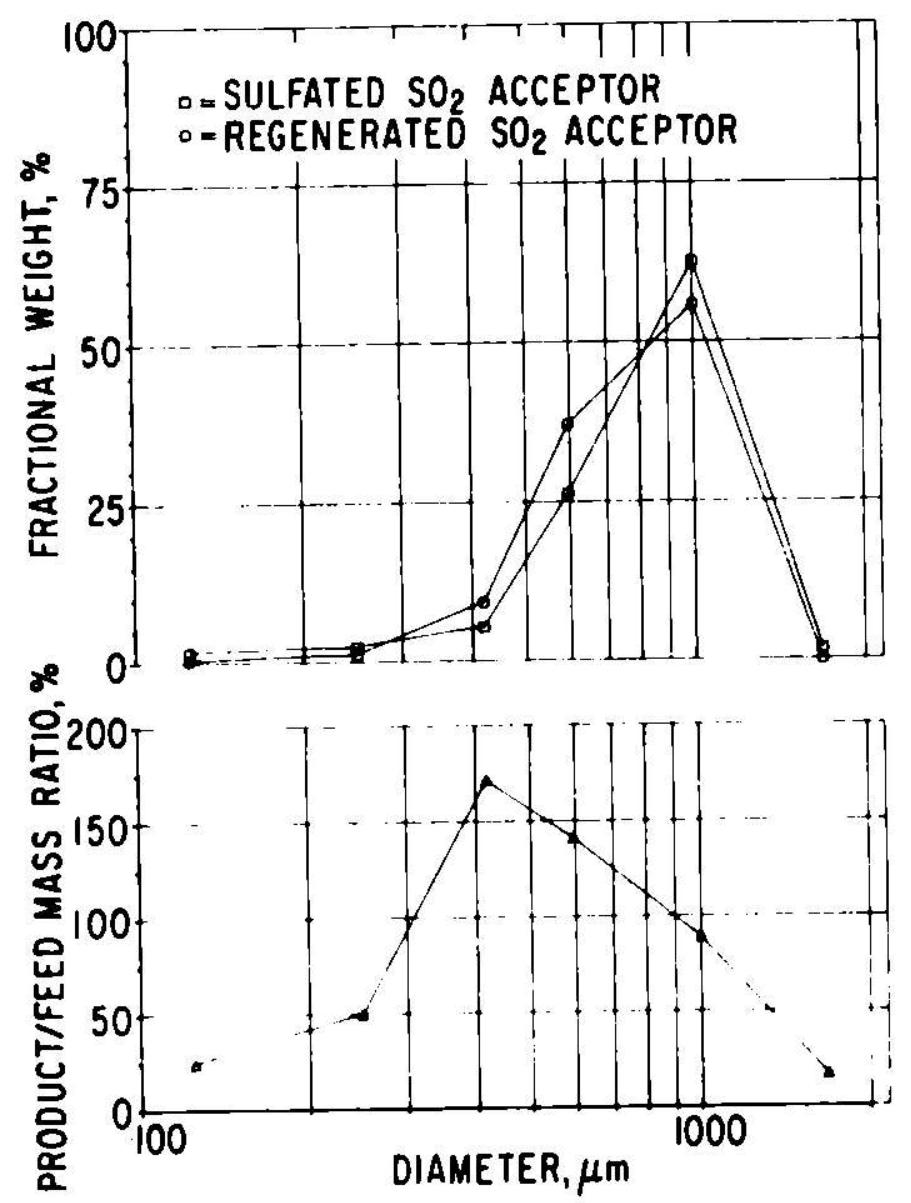

F1g. 11. Exp-1, fractional feed and product particle slze distributions (upper graph). Attrition, characterlzed by the fractional product to feed mass ratios at different particle diameters (lower graph).

followed by further defluidization and a temperature excursion in the bed which caused the dolomite particles to fuse. (It was previously reported by Wheelock and Boylan ${ }^{9}$ that the surface of gypsum becomes glassy during regeneration at $1250^{\circ} \mathrm{C}$.) Agglomerates from this attempted experiment have been analyzed by $X$-ray diffraction. In the fused portion, calc lum-magnesium sllicate compounds (which are absent in virgin dolomite) were found. When this class of materials is pure, the melting point $1 \mathrm{~s} \sim 1300^{\circ} \mathrm{C}$. The agglomeration protlem is further accentuated by the presence of coal ash because at the temperature and reducing conditions of the regeneration reactor, most coal ashes sof ten. 
I1. REGENERATION OF TYMOCHTEE DOLOMITE USING COAL AS THE FUEL

At the completion of the above investigation, the PDU regeneration system (including the reactor) was modified and features were added which permit the combustion of coal. In the subsequent investigations, incomplete combustion of coal in a fluidized bed of partially sulfated dolomite generated both the heat and the required reducing gases for the regeneration reactions.

The effects of solids residence time in the reactor, regeneration temperature, and pressure on the extent of $\mathrm{CaO}$ regeneration in the sulfated Tymochtee dolomite, the $\mathrm{SO}_{2}$ concentration in the dry off-gas, and the buildup of $\mathrm{CaS}$ were evaluated.

\section{Experimental}

The modified regeneration system used in this investigacion is shown schematically in Fig. 12. The reactor ID was expanded from $7.62 \mathrm{~cm}(3.0 \mathrm{in.})$ in the previous investigation to $10.8 \mathrm{~cm}$ (4.25 in.), and the height of the fluidized bed $(246 \mathrm{~cm})$ was regulated by an overflow pipe that is external to the fluidized bed. The pressurized, fluidized-bed reactor was lined with a 4.8-cm-thick castable refractory. The coal and the sulfated sorbent flows were metered separately (for independent control) to a common pneumatic transport line which discharged into the fluldized bed $\sim 15 \mathrm{~cm}$ above the gas distributor, as shown in Fig. 13. Thus, two zones were formed: a highly oxidizing zone below the solid injection point, and a reducing zone above the injection point.

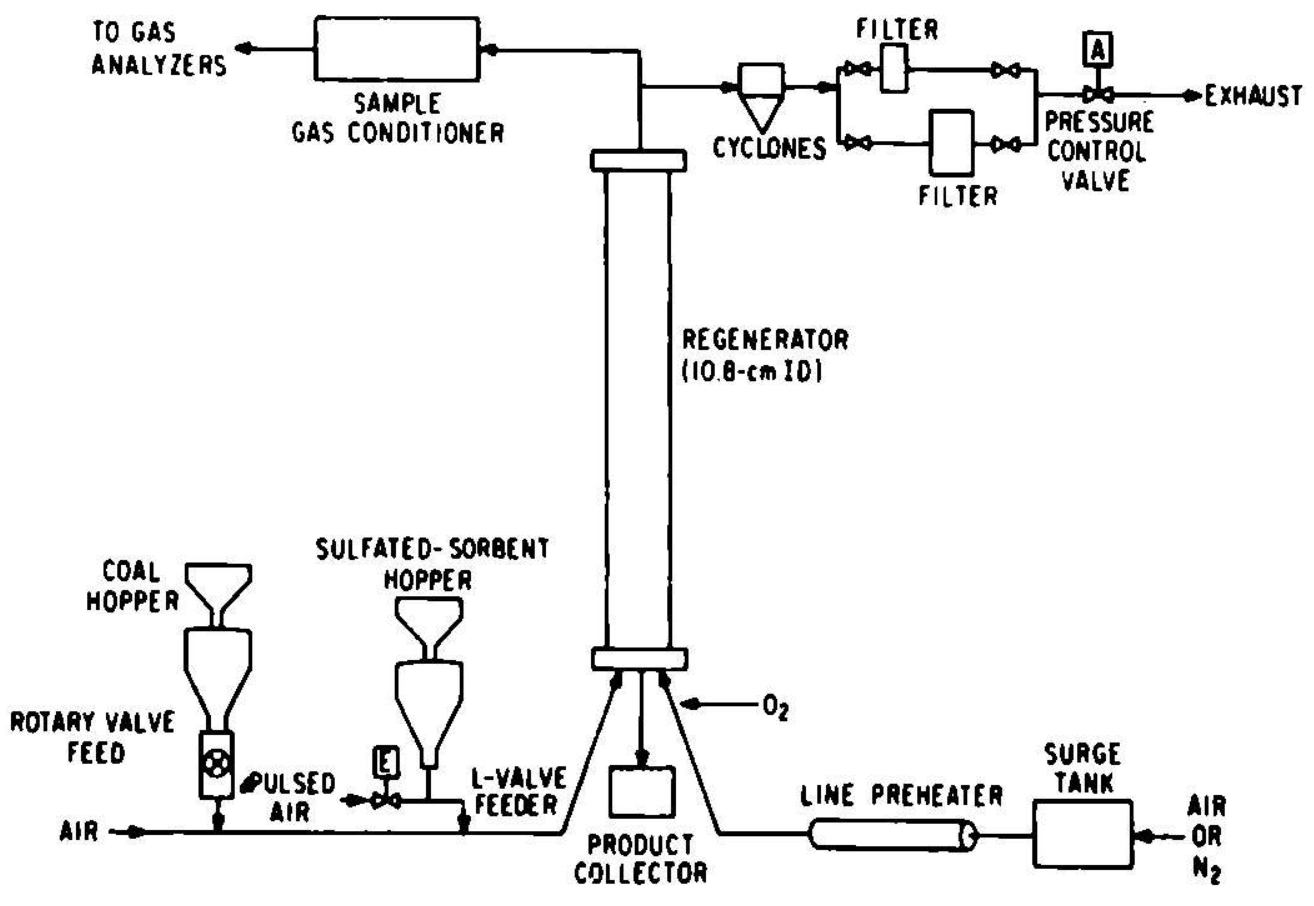

F1g. 12. Experimental sorbent regeneration system 


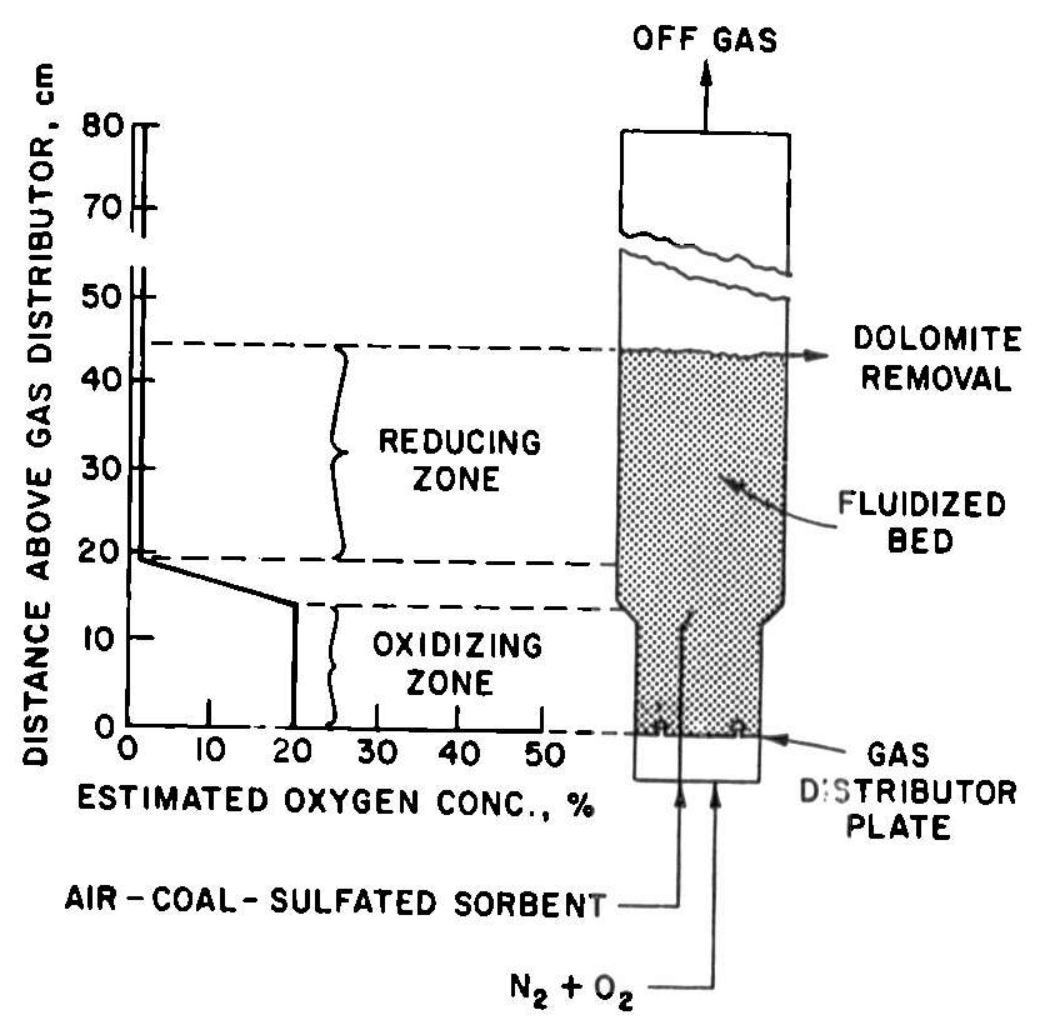

Fig. 13. Schematic diagram of the regeneration reactor used for the experiments with coal and the expected axial oxygen concentration profile.

Other components of the experimental system were similar to those used in the previous regeneration investigation described in Part I of the report. Pertinent constituents $\left(\mathrm{SO}_{2}, \mathrm{O}_{2}, \mathrm{CO}, \mathrm{H}_{2}, \mathrm{CH}_{4}\right.$, and $\left.\mathrm{NO}\right)$ of the of $\mathrm{f}$-gas were continuously analyzed. Solids transport air constituted $240 \%$ of the total fluldizing gas in the reactor. The remalning fluidizing gas was a mixture of pure nitrogen and oxygen.

Oxygen and nitrogen were metered separately and mixed to produce the required oxygen environment in the reactor. Thus the oxygen requirements at different experimental conditions could be satisfied without changing the fluidizing gas velocity. Oxygen concentrations in excess of that in air were used in the feed gas in most of the reported regeneration experiments. Large amounts of heat (per unit capacity) were required to compensate for (1) the heat losses in the relatively small experimental system and (2) the heat load imposed by feeding cold sulfated sorbent to the system. In a large-scale Industrial regeneration system, such heat requirements would not be encountered and oxygen entichment of the fluidizing alr would not be needed.

The Tymochtee dolomite that was regenerated contained $v 9$ wt $\% \mathrm{~S}$ as $\mathrm{CaSO}_{4}$ (no $\mathrm{MgSO}_{4}$ present), $2 \mathrm{~h}$ wt $\% \mathrm{Ca}, 9.5 \mathrm{wt} \% \mathrm{CO}_{2}$, and a nominal size distribution of $-14+30$ mesh before regeneratiou. In 1 ts virgin state, its main constituents were $\mathrm{CaCO}_{3}$ (50 wt \%) and $\mathrm{MgCO}_{3}$ (39 wt \%). 
During regeneration, Triangle coal was combusted under reducing conditions. Ir is a Type B bituminous high-volatile coal (32.6\% volatile matter, dry) and has a high ash fusion temperature $\left(1390^{\circ} \mathrm{C}\right.$, initial deformation under reducing conditions). As received, it contains 73.5 wt $\% \mathrm{C}, 9.4 \mathrm{wt} \%$ ash, and 0.98 wt $\%$ S.

\section{Results and Discussion}

The experimental conditions and results for thirteen experiments are given in Table 3. The experiments were performed at three temperature levels: $1000^{\circ} \mathrm{C}, 1050^{\circ} \mathrm{C}$, and $1100^{\circ} \mathrm{C}$. Solids residence times ranging from $\sim 7 \mathrm{~min}$ to $35 \mathrm{~min}$ were used at each temperature level.

Regeneration of $\mathrm{CaO}$ was calculated from chemical analyses of the steadystate products. It was based on the sulfur to calclum ratios in (1) the sulfated dolomite feed and (2) the steady state product after regeneration. These calculated regeneration values are compared in Table 3 with the values that are based on of $f$-gas analyses. The latter values are the ratios of the total sulfur released into the of $f$-gas stream to the total sulfur contalned in the sulfated-dolomite feed. The off-gas flow rate was calculated using the feed gas rate and the model of the regeneration process (discussed in a later section) in which the gas volumet:ic expansion in the reactor is predicted. The concentrations and rates of the feed and effluent gases are given in Table 4. The $\mathrm{CaO}$ regeneration values obtained by chemical analyses of the regenerated products generally agree within analytical accuracy with the values calculated from of $f$-gas analyses.

Ef fect of Solids Residence Time and Temperature on Regeneration. The extents of regeneration (based on of $f$-gas and regenerated solids analyses) are plotted in Fig. 14 as a function of solids residence time for the three temperature levels. The solids residence time was varied by changing the solids feed rate and not by changing the reactor volume.

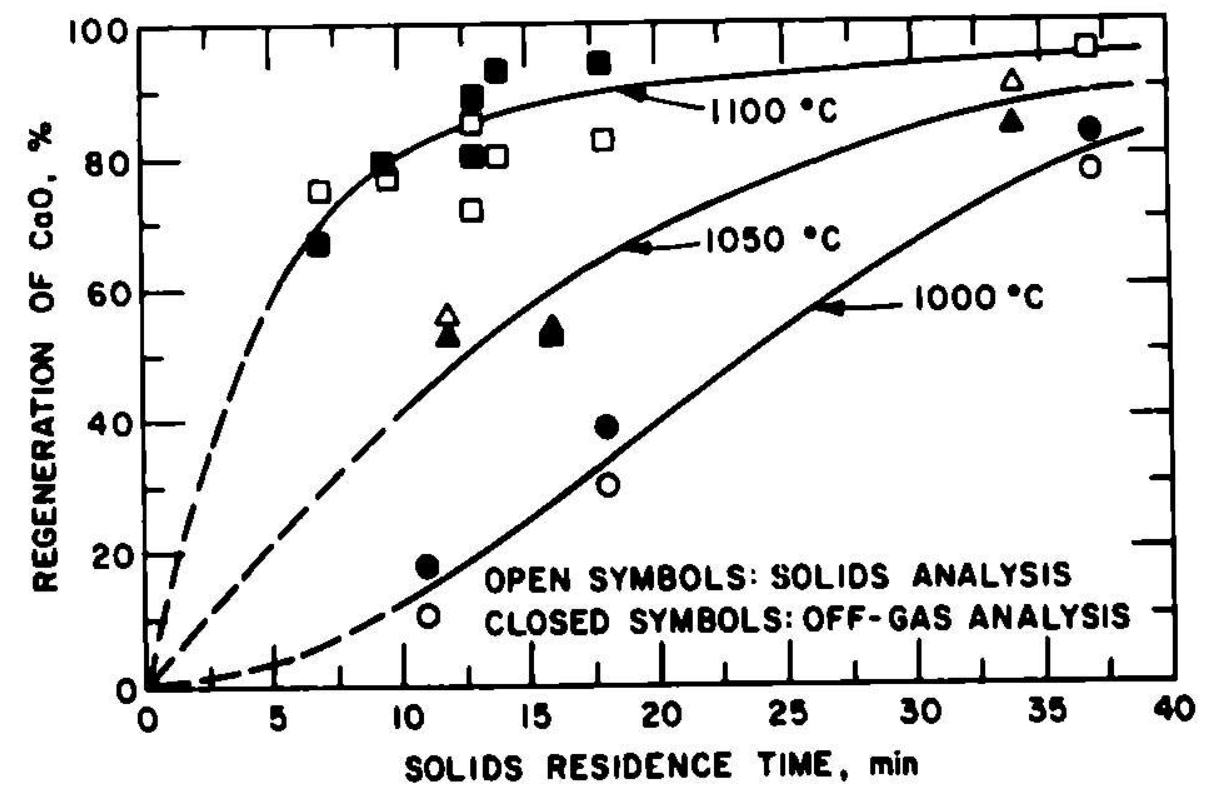

F1g. 14. Regeneration of $\mathrm{CaO}$ in Tymochtee dolomite as a function of solids residence time (pressure: $153 \mathrm{kPa}$ ). 
Table 3. Experimental conditions and results for the regeneration of sulfated Tymochtee dolomite by the incomplete combustion of Triangle coal in a fluidized bed.

Nominal fluidized-bed height: $46 \mathrm{~cm}$

Pressure: $153 \mathrm{kPa}$

Reactor ID: $10.8 \mathrm{~cm}$

Coal: Triangle coal ( 0.98 wt \% S) ash fusion temp. under reducing conditions, 13 yõ $\mathrm{C}$ (initial deformation)

Sorbent: (1) $-14+50$ mesh, 9.0 wt $\%$ S (CS-6, $-7,-8$ )

(2) $-14+50$ mesh, 9.4 wt $\% \mathrm{~S}$ (CS-10, -11, -12)

8.5 wt \% S (CS-13 thru -18 and $\operatorname{CCS}-1$ )

\begin{tabular}{|c|c|c|c|c|c|c|c|}
\hline Exp. & $\begin{array}{l}\text { Temperature, } \\
{ }^{\circ} \mathrm{C}\end{array}$ & $\begin{array}{c}\text { Fluidlzing- } \\
\text { Gas Velocity, } \\
\text { r/sec }\end{array}$ & $\begin{array}{l}\text { Feed } \\
\text { Rate, } \\
\text { kg/hr }\end{array}$ & $\begin{array}{c}\text { Solids } \\
\text { Resideace } \\
\text { TIme, min }\end{array}$ & $\begin{array}{l}\text { Reducing Gas } \\
\text { Concentration } \\
\text { In Effluent, } \%\end{array}$ & $\begin{array}{l}\text { Measured } \\
\mathrm{SO}_{2} \text { in Dry } \\
\text { Off-Gas, \% }\end{array}$ & $\begin{array}{c}\text { CaO } \\
\text { Regeneration, } \\
\% a / \% b\end{array}$ \\
\hline$c S-6$ & 1000 & 0.98 & 5.0 & 37 & 1.4 & 2.5 & $83 / 77$ \\
\hline CS-8 & 1000 & 0.92 & 10.0 & 18 & 2.2 & 2.5 & $39 / 30$ \\
\hline CS-17 & 1000 & 1.04 & 16.1 & 11 & 2.4 & 1.4 & $18 / 11$ \\
\hline $\mathrm{CS}-7$ & 1050 & 0.92 & 5.4 & 34 & 1.9 & 3.0 & $84 / 90$ \\
\hline CS-16 & 1050 & 1.0 & 11.1 & 16 & 2.2 & 3.3 & $53 / 53$ \\
\hline CS-10 & 1050 & 0.98 & 15.0 & 12 & 2.5 & 4.8 & $53 / 56$ \\
\hline CS-15 & 1100 & 1.02 & 5.0 & 37 & 1.5 & 2 & $82 / 95$ \\
\hline CS-14 & 1100 & 1.05 & 10.0 & 18 & 2.2 & 4.8 & $94 / 82$ \\
\hline CS-11 & 1100 & 1.07 & 14.3 & 13 & 2.9 & 6.4 & $80 / 85$ \\
\hline CS-13 & 1100 & 1.09 & 31.6 & 13 & 2.2 & 6.1 & $89 / 72$ \\
\hline$C S-18$ & 1100 & 1.07 & 13.2 & 14 & 2.4 & 6.3 & $93 / 80$ \\
\hline CS-12 & 1100 & 1.16 & 19.5 & 9.4 & 2.9 & 7.8 & $79 / 77$ \\
\hline $\operatorname{cCs}-1$ & 1100 & 1.43 & 26.4 & 7.0 & 2.7 & $6.5^{c}$ & $67 / 75$ \\
\hline
\end{tabular}

a Based on off-gas analysis.

based on chemical analysis of dolomite samples.

The $\mathrm{SO}_{2}$ concentration adjusted for a $1.08 \mathrm{~m} / \mathrm{sec}$ fluidizing-gas veiocity is $8.7 \%$. 
Table 4. Rates and concentrations of feed and $\in f f$ luent gases.

\begin{tabular}{|c|c|c|c|c|c|c|c|c|c|c|c|c|c|c|}
\hline \multirow{2}{*}{ Exp. } & \multicolumn{5}{|c|}{ Feed Gas } & \multirow{2}{*}{\multicolumn{9}{|c|}{ Effluent Gas (wet) }} \\
\hline & $\begin{array}{l}\text { Rate, } \\
\text { l./mina }\end{array}$ & $\begin{array}{l}\text { Solids } \\
\text { Transport } \\
\text { Alr, } \%\end{array}$ & $\begin{array}{r}\text { Tank } \\
\mathrm{N}_{2}, \quad \%\end{array}$ & $\begin{array}{r}\text { Tank } \\
\mathrm{o}_{2}, \%\end{array}$ & $\begin{array}{l}\text { Total } \\
\mathrm{O}_{2}, \%\end{array}$ & & & & & & & & & \\
\hline 1 & 186.6 & 44.6 & 47.2 & 8.2 & 17.4 & 209.2 & 0.84 & 0.19 & 0.19 & 0.09 & 2.33 & 0.018 & 14.5 & 6.65 \\
\hline 2 & 174.2 & 47.8 & 40.2 & 12.0 & 21 . & 201.1 & 1.29 & 0.41 & 0.27 & 0.18 & 1.93 & 0.007 & 24.4 & 8.08 \\
\hline 3 & 197.1 & 41.2 & 43.5 & 15.2 & 23.8 & 227.1 & 1.28 & 0.50 & 0.34 & 0.0 & 1.09 & 0.068 & 30.2 & 8.53 \\
\hline 4 & 167.4 & $49 \ldots$ & 39.8 & 10.5 & 20.8 & 182.8 & 1.25 & 0.23 & 0.25 & 0.14 & 2.49 & 0.009 & 21.7 & 7.76 \\
\hline 7 & 179.0 & 44.9 & 43.0 & 1.20 & 21.3 & 203.7 & 1.29 & 0.14 & - & - & 1.62 & 0.157 & 26.7 & 7.65 \\
\hline 8 & 191.7 & 42.4 & 38.7 & 18.9 & 27.7 & 232.4 & 1.73 & 0.18 & 0.18 & 0.19 & 4.4 & 0.045 & 23.6 & 9.17 \\
\hline 9 & 188.0 & 44.3 & 32.1 & 23.6 & 32.8 & 239.7 & 2.15 & 0.07 & 0.18 & 0.09 & 5.7 & 0.009 & 24.6 & 10.35 \\
\hline 10 & 192.9 & 42.1 & 33.3 & 24.5 & 33.2 & 241.7 & 1.71 & 0.27 & - & 0 & 4.8 & 0.09 & 32.4 & 9.97 \\
\hline 11 & 187.8 & - & - & - & 33.0 & 235.3 & - & - & - & - & 4.95 & - & - & 10.00 \\
\hline 12 & 204.2 & 40.8 & 31.5 & 27.7 & 36.2 & 267.5 & 2.14 & 0.09 & 0.18 & 0.05 & 6.9 & 0.009 & 29.0 & 11.03 \\
\hline 13 & 251.2 & 31.4 & 48.5 & 20.1 & 26.6 & 333.3 & 2.13 & 0.22 & - & 0 & 4.89 & 0.017 & 37.3 & 11.12 \\
\hline
\end{tabular}

${ }^{\text {a At }} 101.3 \mathrm{kPa}$ and $22.8^{\circ} \mathrm{C}$. 
At $1000^{\circ} \mathrm{C}$, as the solids residence time was varied from $37 \mathrm{~min}$ to $11 \mathrm{~min}$, the extent of regeneration decreased drastically from $77 \%$ to $11 \%$ (based on solids analyses). The $\mathrm{SO}_{2}$ concentrations in the dry off-gas decreased from $2.5 \%$ to $1.4 \%$. At this relatively low temperature, the rate of regeneration of $\mathrm{CaO}$ is low, and therefore long solids residence times are required to obtain acceptable $(\geq 50 \%)$ regeneration levels.

At $1050^{\circ} \mathrm{C}$, decreasing the solids residence time from $34 \mathrm{~min}$ to $12 \mathrm{~min}$ decreased the extent of CaO regeneration from $90 \%$ to $56 \%$. The $\mathrm{SO}_{2}$ concentration in the dry off-gas increased from $3.0 \%$ to $4.8 \%$. At $1100^{\circ} \mathrm{C}$, the highest temperature level investigated, decreasing the solids residence time from $37 \mathrm{~min}$ to $7.0 \mathrm{~min}$ caused the extent of $\mathrm{CaO}$ regeneration to decrease from $95 \%$ to $75 \%$ and the $\mathrm{SO}_{2}$ concentration to increase from $2 \%$ to $8.7 \%$, (The $\mathrm{SO}_{2}$ concentration for the experiment with a $7-\mathrm{min}$ solids residence time [Exp. (CS-1)] was adjusted from $6.5 \%$ to $8.7 \%$ to compensate for the dilution due to the higher fluidizing-gas velocity.) Because the rate of regeneration of $\mathrm{CaO}$ is $\mathrm{h} / \mathrm{gh}$ at $1100^{\circ} \mathrm{C}$, the extent of regeneration remalned relatively high when the solids residence time was as low as $7 \mathrm{~min}$.

An improved rate of $\mathrm{CaSO}_{4}$ decompostition at higher temperatures $\left(\sim 1100^{\circ} \mathrm{C}\right)$ for the reductive decomposition of gypsum has also been reported by numerous workers, including Martin et $a l .^{3}$ who used carbon as the reductant and Wheelock et al. ${ }^{9}$ who used $\mathrm{CO}$ as the reductant. As expected, the oxygen requirement in the feed gas increased with (1) the sulfated sorbent feed rate and (2) the total amount of recuctive uecomposition, wilicil is represented by the $\mathrm{SO}_{2}$ concentration in the off-gas.

Regression Analysis of Regeneration Data. A best fit has been obtained by regression analysis, for the experimental extent of $\mathrm{CaO}$ regeneration as a function of regeneration temperature and solids residence time. The equation 18

$$
\ln (1-R)=A \cdot \tau+B \cdot \tau^{2}
$$

where $R$ r extent of CaO regeneration (i.e., at complete regeneration, $R=1$ )

$\tau$ - particle residence time in the reactor, min

$A, B=$ functions of temperature.

The temperature-dependent constants $A$ and $B$ we re evaluated at the three regeneration temperature levels investigated $\left(1000,1050\right.$, and $\left.1100^{\circ} \mathrm{C}\right)$ by least squares technique. From these values, a quadratic equation was obtained to represent the functional dependence of $A$ and $B$ on regeneration temperature as glven below.

$$
\begin{aligned}
& A \times 10^{2}=-5.05-8.72 \mathrm{~T}-4.00 \mathrm{~T}^{2} \\
& B \times 10^{4}=-2.94+18.64 \mathrm{~T}+10.65 \mathrm{~T}^{2} \\
& \mathrm{~T}=(t-1050) / 50
\end{aligned}
$$

where $t=$ regeneration temperature, ${ }^{\circ} \mathrm{C}$

The values calculated with the model equation, Eq. 9, compare well with the experimental results. A correlation coefficlent ranging from 0.96 
to 0.99 was obtained for the experimental data and the results calculated from the model equation. Equation 9 with the calculated coefficients was found to be a good mathematical model of the dependence of the extent of $\mathrm{CaO}$ regeneration on regeneration temperature and solids residence time in the reactor for the investigated experimental range. This relationship for the rate of $\mathrm{CaO}$ regeneration has been used in a mass and energy-constrained model for the regeneration process to predict sorbent behavior within and outside the investigated operating range.

The extent of $\mathrm{CaO}$ regeneration as a function of temperature and sorbent residence time as calculated by Eq. 9 has been plotted in Fig. 15. The plot has been extrapolated to $1200^{\circ} \mathrm{C}$, which is beyond the experimentally investigated temperature range of $1000-1100^{\circ} \mathrm{C}$. On the basis of these predictions, it is expected that the extent of $\mathrm{CaO}$ regeneration would increase considerably (by $\sim 1 / 3$ ) if the temperature were increased from $1100^{\circ} \mathrm{C}$ to $1150^{\circ} \mathrm{C}$ at a solids residence time of 5 to $7.5 \mathrm{~min}$. At higher temperatures, the extent of regeneration does not significantly increase above that at $1150^{\circ} \mathrm{C}$.

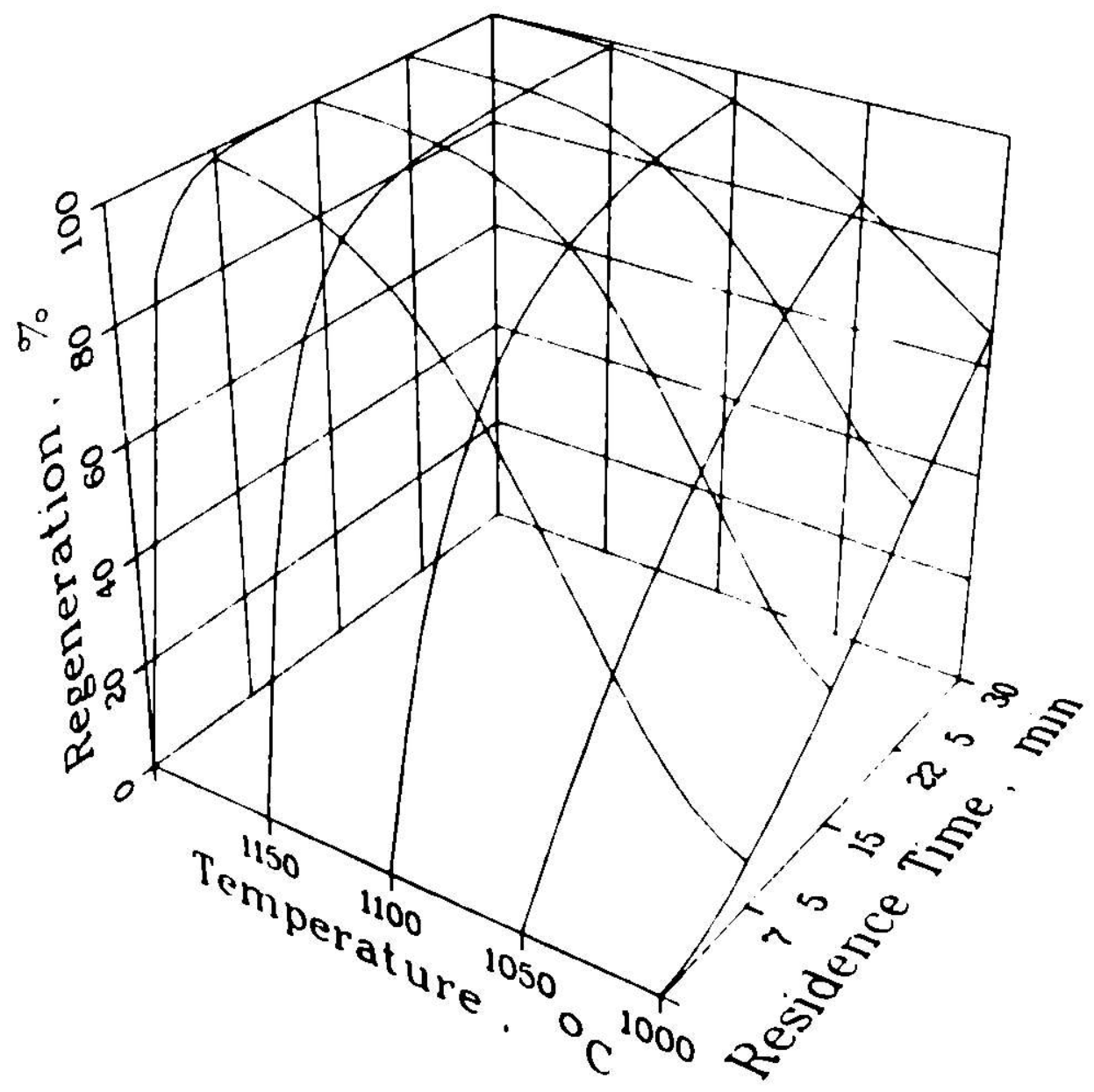

F18. 15. The extent of CaO regeneration for Tymochtee dolomite as a function of temperature and residence $t$ ime as represented by the model equation, Eq. 9. 
Analysis of Variance of Regeneration Data. The series of regeneration experiments presented in Table 3 (excluding experiment CCS-1), constitutes a $3^{2}$ factorial experimental design plus three replicate experiments. As described in the preceding section, they were designed to measure the effects of sorbent residence time in the reactor and reactor temperature on (1) the extent of $\mathrm{CaO}$ regeneration and (2) $\mathrm{SO}_{2}$ concentration in the off-gas. Table 5 summarizes the design conditions for the experiments whereas the actual experimental conditions are given in Table 3.

An analysis of variance performed for the extent of regeneration as calculated from flue gas and solids analyses is summarized in Table 6. According to the F-test for significance at the $\alpha=0.1$ leve 1 ( $90 \%$ confidence leve1), both the residence time and the temperature have a significant effect on the extent of regeneration. However, no significant difference was ind cated between extents of regeneration based on the two methods of calculations: (1) by off-gas analyses and (2) by solids analyses. (This indicates that the analyses agree within analytical accuracy and that no constant difference exists between the two analytical methods.)

The validity of this analysis depends on the absence of interactions between the controlled variables. For a $3^{2}$ factorlal experimental design, the model equation is expressed by:

$$
x_{1 j}=\mu+\alpha_{1}+\beta_{j}+I_{1 j}+\varepsilon_{1 j}
$$

where $X_{1 j}$ is the observed response, $\mu$ is the mean of all posstble resi ises, $\alpha_{1}$ and $B_{j}$ are the treatment effects, $I_{1 j}$ is the interaction effect, and $\varepsilon_{1 j}$ is the error between the observed and the expected response.

Analysis of the variance for a factorial experimental design with partial replication cannot estimate the effect of the term $I_{1 j}$. The term $I_{1 j}$ is included in the term $\varepsilon_{1 j}$. In addition to inflating the error mean square, the presence of an interaction can give misleading results in F-tests for significance. Comparing the error mean square (192) with the variance calculated from the replicate experiments (46) gives an Indication of the extent that interaction has inflated the error mean square. Since both of these values are estimates of $\sigma^{2}$ (the true varlance of the response data), the difference may indicate an interaction between the controlled variables.

Effect of Solids Residence Time and Temperature on $\mathrm{SO}_{2}$ Concentration in the off-Gas. The measured $\mathrm{SO}_{2}$ concentrations in the dry off-gas for the experiments (Table 3) are plotted in Fig. 16. The best fit relationship (Eq. 9) for the functional dependence of $\mathrm{CaO}$ regeneration on solids residence time for the three temperature levels investigated was used in the model for the regeneration process (described in a later section of this report), and the $\mathrm{SO}_{2}$ concentration in the dry off-gas was calculated for solids residence $t$ imes ranging from 40 to $\sim 2.5 \mathrm{~min}$. The calculations were made for the three Investigated temperature levels, a pressure of $153 \mathrm{kPa}$, and a fluidizing-gas velocity of $1.07 \mathrm{~m} / \mathrm{sec}$. A sulfur content of 9.5 wt $\%$ was assumed for the sulfated dolomite. The calculated (predicted) $\mathrm{SO}_{2}$ concentration in the dry off-gas are plotted in Fig. 16, together with the experimentally 
Table 5. Design conditions anf inatrix representation for the $3^{2}$ factorial experimental design.

Equipment: $10.8-\mathrm{cm}-\mathrm{ID}$ fluidized-bed regenerator Fluidized-Bed Height: $46 \mathrm{~cm}$

Pressure: $153 \mathrm{kPa}$

Fluidizing-Gas Velocity: $1.07 \mathrm{~m} / \mathrm{sec}$

Reducing Gas in off-Gas: $\sim 2.3 \%$

\begin{tabular}{crrr} 
& \multicolumn{2}{c}{ Levels of } & Independent Var1ables \\
\hline Variable & Level 1 & Level & Level 3 \\
\hline t, Temperature, ${ }^{\circ} \mathrm{C}$ & 1000 & 1050 & 1100 \\
R, Residence Time, mir & 37 & 18 & 12 \\
\hline
\end{tabular}

Matrix Representation of Experimental Conditions

$t_{1} t_{2} \quad t_{3}$

\begin{tabular}{|c|c|c|c|}
\hline $\mathrm{R}_{1}$ & $\mathrm{CS}-6$ & Cs-7 & CS -15 \\
\hline $\mathbf{R}_{2}$ & CS-8 & CS-16 & CS-14 \\
\hline $\mathbf{R}_{3}$ & $\mathrm{CS}-17$ & $\mathrm{CS}-10$ & $\operatorname{cs}-11^{a}$ \\
\hline
\end{tabular}

${ }^{a_{\text {Three }}}$ replicate (CS-12, $\mathrm{CS}-13$, and $\mathrm{CS}-18$ ) were made of this experimental condition.

Table 6. Analysis of varlance of extent of CaO regeneration data, CS series of experiments.

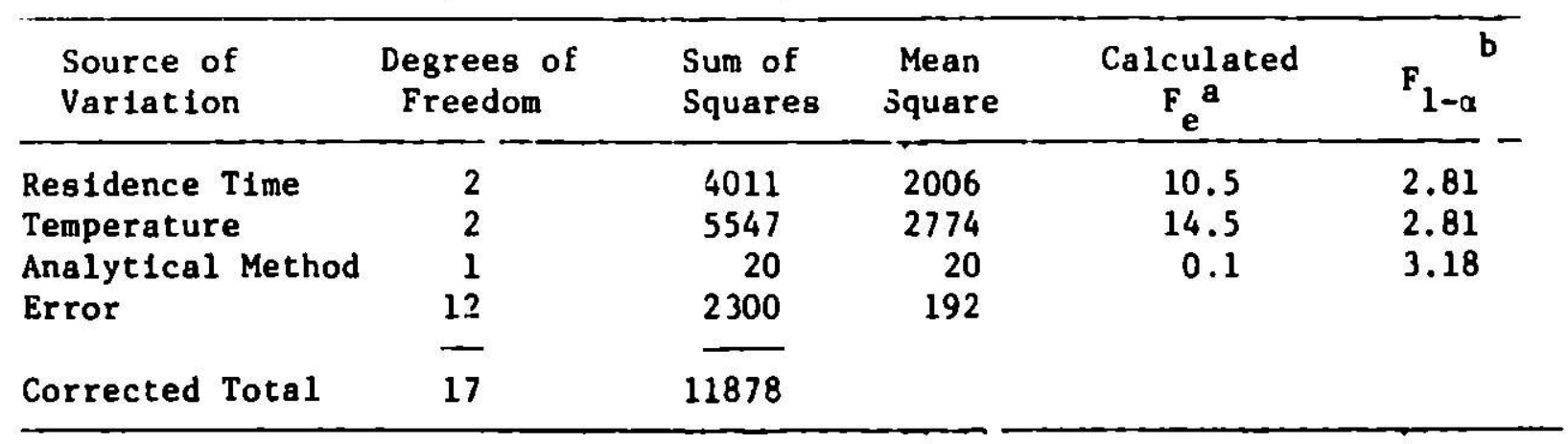

${ }^{a} F_{e}$ - Ratio of varlable mean square to error mean square.

$b_{a}=0.1$ (90\% confidence level). 


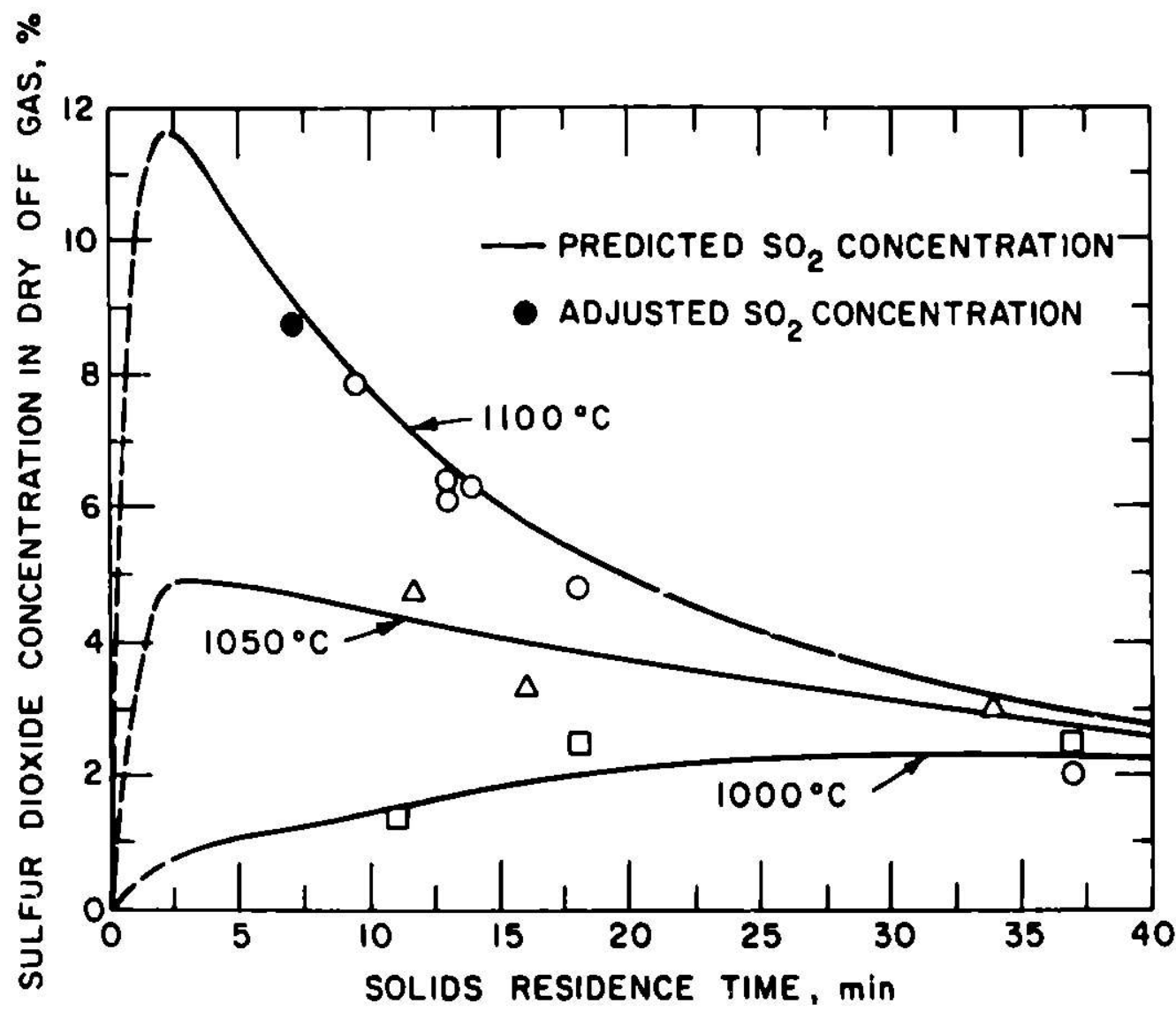

F1g. 16. Predicted and experimental $\mathrm{SO}_{2}$ concentration as a function of solids residence time at three regeneration temperatures (pressure: $153 \mathrm{kPa}$ ).

obtained concentrations. The experimental and predicted $\mathrm{SO}_{2}$ concentrations in the dry off-gas for all three temperature levels were in good agreement.

At $1000^{\circ} \mathrm{C}$, the $\mathrm{SO}_{2}$ concentration in the dry of $\mathrm{f}-\mathrm{gas}$ is predicted to continually decrease as the solids residence time decreases, in agreement with the experimental data. At this temperature, the regenerat ion rate was low. At $1050^{\circ} \mathrm{C}$ and $1100^{\circ} \mathrm{C}$, the $\mathrm{SO}_{2}$ concentration is predicted to be maximum at the lowest permisstble solids residence $t$ ime of $22.5 \mathrm{~min}$, at which point the process oxygen requirement is greater than the quantity of total fluidizing gas.

At $1100^{\circ} \mathrm{C}$, much higher $\mathrm{SO}_{2}$ concentrations were experimentally obtained and predicted. For a $5-\mathrm{min}$ solids residence time (realistic), an $\mathrm{sn}_{2}$ concentration in excrss of $10 \%$ is predicted.

At $1100^{\circ} \mathrm{C}$, the experimental $\mathrm{SO}_{2}$ concentrat ions increased from $2 \%$ to $8.7 \%$ as the solids residence $t$ ime was decreaged from $37 \mathrm{~min}$ to $7 \mathrm{~m} 1 \mathrm{n}$. These exper imental results show that for temperatures $>1050^{\circ} \mathrm{C}$, as the solids residence time in the reactor is decreased ( $i . e .$, at higher rates of sulfated sorbent throughput), extent of regeneration 1 s sacrificed but $\mathrm{SO}_{2}$ concentra$t$ ion in the dry off-gas is increased. The poselble kinetic effect of introducing room-temperature sorbent for very short solids residence $t$ imes, < $7 \mathrm{~min}$, has not yet been evaluated. 
With Eq. 9 used for the functional dependence of extent of CaO regeneration on temperature and solids residence time in the above-mentioned model for the regeneration process, the $\mathrm{SO}_{2}$ concentrations in the dry off-gas were also predicted at three different system pressures and are given in Fig. 17. These predictions were extrapolated beyond the experimentally investigated cemperature range of $: 000-1100^{\circ} \mathrm{C}$. The effect of pressure on $\mathrm{SO}_{2}$ concentration is very large, as discussed below. It is predicted that with a system pressure of $1000 \mathrm{kPa}(10 \mathrm{~atm}), \mathrm{SO}_{2}$ concentrations no greater than $4 \%$ can be obtained, even with regeneration temperatures as high as $1200^{\circ} \mathrm{C}$ and solids residence times as short as $5 \mathrm{~min}$. At a pressure of $100 \mathrm{kPa}$ ( $1 \mathrm{~atm}), \mathrm{SO}_{2}$ concentrations as high as $20 \%$ are predicted at regeneration temperatures up to $1200^{\circ} \mathrm{C}$. However, based on the experfence to date with the regeneration process at ANL and by Skopp et al., ${ }^{5}$ it is expected that regeneration temperatures in excess of $1100^{\circ} \mathrm{C}$ will not be feasible because of an increased tendency of the sulfated sorbent (a mixture of sorbent and residual coal ash) to agglomerate. Also, high temperatures $\left(>1100^{\circ} \mathrm{C}\right)$ may have a detrimental effect on the reactivity of the sorbents in subsequent sulfation cycles.

Higher temperatures were found to increase both the extent of CaO regeneration and the $\mathrm{SO}_{2}$ concentration in the off-gas. This effect of temperature agrees with previous results presented in Section I, in which methane was used as the fuel for the regeneration of dolomite by reductive decomposition. Increased $\mathrm{SO}_{2}$ concentrations in the of $\mathrm{f}$-gas at higher regeneration temperatures have also been reported by Hoke et $a l .{ }^{8}$ for the reductive decomposition of pure $\mathrm{CaSO}_{4}$ in a fluidized-bed batch regeneration. Based on the above results with Tymochtee dolomite, an Industrial regeneration process should be operated at $1100^{\circ}$ and a solids residence time of $\sim 5-8 \mathrm{~min}$. The $\mathrm{SO}_{2}$-enriched of $\mathrm{f}-\mathrm{gas}$ from the regeneration process operated at a pressure of $100 \mathrm{kPa}(1 \mathrm{~atm}) \mathrm{can}$ be expected to contain $\sim 10-13 \% \mathrm{SO}_{2}$ at best, without of $\mathrm{f}-\mathrm{gas}$ recycle.

Effect of System Pressure on Extent of $\mathrm{CaO}$ Regeneration and of $\mathrm{f}-\mathrm{Gas}_{8} \mathrm{SO}_{2}$ Concentration. Thermodynamically, from an equilibrium standpoint, when the system pressure 1s lowered, the $\mathrm{SO}_{2}$ concentration in the off-gas will increase. In the fluldized-bed process, the $\mathrm{SO}_{2}$ concentration in the of $\mathrm{f}$-gas is determined by the rate of total gas flow through the reactor and the rate of $\mathrm{CaO}$ regeneration in the reactor. Because the air requirements (f 1.didizing gas and/or combustion oxygen) and energy requirements (sensible heats of gas and solids, and the heats for the decomposition reactions) of the process are high, equilibrium $\mathrm{SO}_{2}$ concentrations in the of $\mathrm{f}-\mathrm{gas}$ cannot be achieved practically. At low pressures, less fluidizing gas is required and thus the extent of dilution is reduced.

The effect of system pressure on the extent of regeneration of $\mathrm{CaO}$ and the $\mathrm{SO}_{2}$ concentration in the dry of $f-g a s$ has been evaluated in $s 1 x$ experiments in which sulfated Tymochtee dulomite from the second and sixth regeneration cycles of a ten-cycle experiment was regenerated. The experimental conditions and results are given in Table 7. In experiments CCS $-2 A,-2 B$, and $-2 C$, the pressure was $\sim 115 \mathrm{kPa}$ or $\sim 75 \%$ of that in CCS-2. In the experiments at the lower pressure, decressing solids residence time from $8.8 \mathrm{~m} / \mathrm{n}$ to $5.3 \mathrm{~min}$ caused 


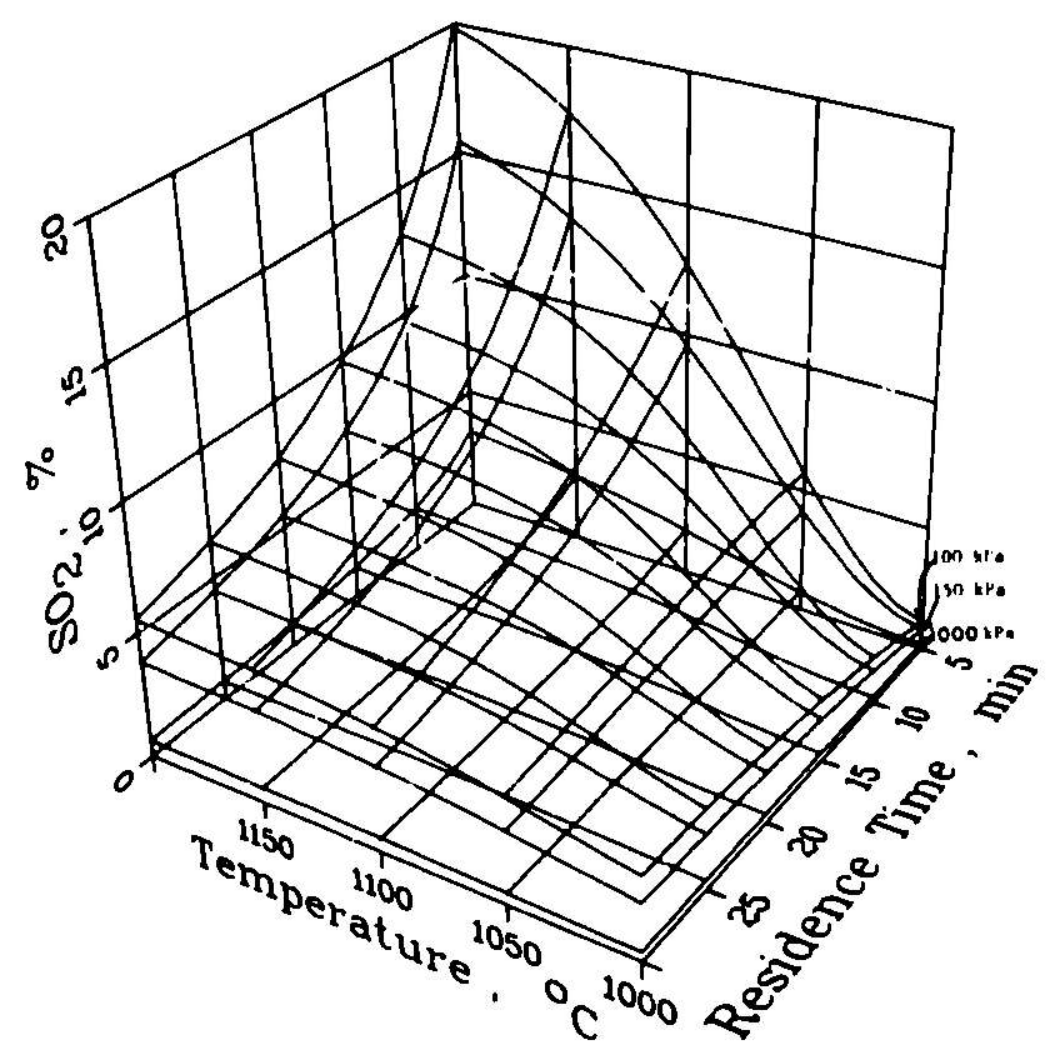

F1g. 17. Predicted $\mathrm{SO}_{2}$ concentration in the try of $f$-gas as a function of solids residence time, regeneration temperature, and system pressure.

Experimental Conditions Solid Feed Temp, ${ }^{\circ} \mathrm{C}: 815$

Fluidizing-Gas Velocity, m/sec: 1.07

Fluidizing-Gas Feed Temp, ${ }^{\circ} \mathrm{C}: 650$

Sulfur Concentration in Sorbent, \%: 9.5

the extent of CaO regeneration to decrease from $80 \%$ to $60 \%$ (based on solids analys 18). These results on extent of regeneration are in agreement with those obtained at the h1gher pressure of $153 \mathrm{kPa}$ (see F18. 14) and equivalent sollds residence times. Specifically, results for CCS-2B and CCS-2 agree well.

At the lower pressure, the measured $\mathrm{SO}_{2}$ concentration in the dry off-gas increased from 8.97 to $9.6 \%$ as the solids residence $t$ ime was decreased from $8.8 \mathrm{~min}$ to $5.3 \mathrm{~min}$. These concentrations are higher than those obtained in the higher pressure experiments (Table 3 and Fxp. CCS-2). A larger difference, and a more accurate comparison between off-gas $\mathrm{SO}_{2}$ concentrat lons $f$ rom the lower and higher pressure experiments, would be obtained by adjusting the concentrations for a common fluidizing-gas velocity of $1.07 \mathrm{~m} / \mathrm{sec}$ (the velocity used for predictions in $\mathrm{Fig}_{8}$. 17) as given in Table 7. The adjusted $\mathrm{SO}_{2}$ concentrations could then be compared with the results in Fig. 17 . 
Table 7. Effect of regeneration pressure on the regeneration of Tymochtee dolomite and the $\mathrm{SO}_{2}$ concentration in the off-gas.

Nominal fluidized-bed height: $46 \mathrm{~cm}$

Reactor ID: $10.8 \mathrm{~cm}$

Temperature: $1100^{\circ} \mathrm{C}$

Reducing gas concentration in of $\mathrm{f}-\mathrm{gas}$ : $3.0-3.2 \%$

Coal: Triangle coal (0.98 wt \% s)

Sorbent: $-14+30$ mesh, sulfated dolomite in the second

$(10.7 \mathrm{wt} \% \mathrm{~s})$ and sixth $(9.3 \mathrm{wt} \% \mathrm{~s})$ utilization

cycles.

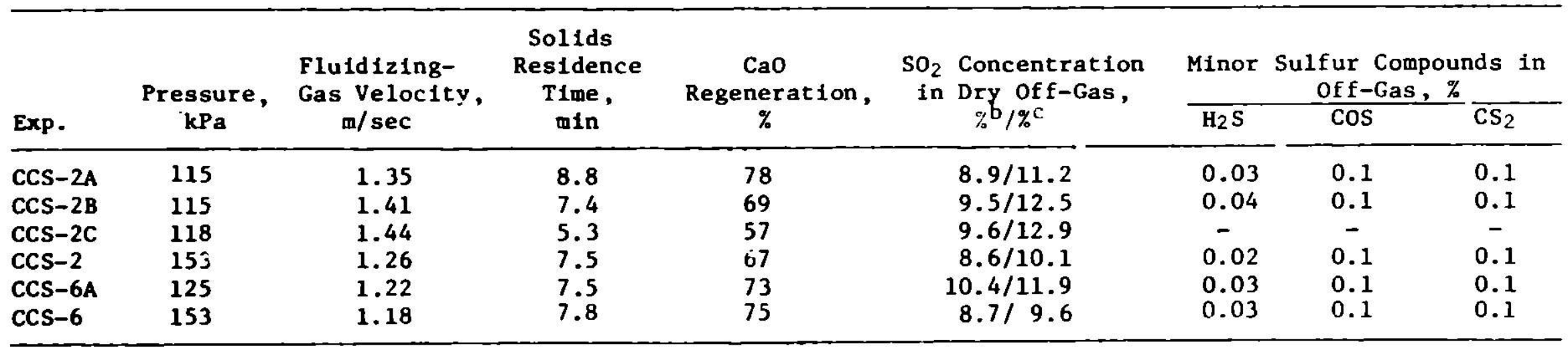

aased on chemical analysis of dolomite samples.

Measured $\mathrm{SO}_{2}$ concentration.

Adjusted $\mathrm{SO}_{2}$ concentration based on a constant fluidizing-gas velocity of $1.07 \mathrm{~m} / \mathrm{sec}$. 
During the regeneration step of the sixth utilization cycle of the cyclic experiments, an additional experiment (CCS-6A) was performed at a reduced pressure, $125 \mathrm{kPa}$ instead of $153 \mathrm{kPa}$ (CCS-6). The experimental conditions and results for both of these experiments are also presented in Table 7. As a result of lowering the system pressure by $220 \%$ while the fluidizing-gas velocity was maintained almost constant $(\sim 1.2 \mathrm{~m} / \mathrm{sec})$, the $\mathrm{SO}_{2}$ concentration in the dry off-gas increased by $220 \%$ from $8.7 \%$ to $10.4 \%$ (the highest $\mathrm{SO}_{2}$ concentration obtained to date). The $\mathrm{SO}_{2}$ concentration in the of $f$-gas increased because of less dilution at the reduced pressure.

Relatively high $\mathrm{SO}_{2}$ concentrations ( $28 \%$ ) have also been reported by Gordon et $a l^{10}$ for the regeneration of 11 mestone at atmospheric pressure. Although the number of experiments in this evaluation was limited and the pressure variation was small, the system pressure was found to have a negligible effect on the rate of $\mathrm{CaO}$ regeneration because the $\mathrm{SO}_{2}$ concentration in the of $f$-gas was not near equilibrlum. However, pressure has been found to affect the $\mathrm{SO}_{2}$ concentration in the off-gas via the extent of dilution.

Formation of CaS. The sulfated dolomite before regeneration contained negligible amounts of $\mathrm{CaS}$. The bulldup of CaS during regeneration of Tymochtee dolomite for all experiments, including those performed at $1000^{\circ} \mathrm{C}$, was found to be $\leq 0.1$ wt $\%\left(\mathrm{~s}^{2-}\right)$. The investigated ranges of temperature, solids residence time, and system pressure had no significant effect on the bulldup of CaS because of the existence of an oxidizing zone at the bottom of the fluidized bed, as discuss id in Section I of this report.

\section{MASS AND ENERGY CONSTRAINED MODEL FOR THE REGENERATION PROCESS}

A first-generation mass and energy constrained model for the one-step regeneration process was developed and used to predict the effects of experimental variables on:

$$
\begin{aligned}
& \text { 1. Off-gas composition }\left(\mathrm{SO}_{2}, \mathrm{CO}_{2}, \mathrm{H}_{2} \mathrm{O} \text {, etc. }\right) \\
& \text { 2. Volumetric gas changes } \\
& \text { 3. Fuel and oxygen requirements } \\
& \text { 4. Individual energy terms } \\
& \text { 5. Fuel cost and consumption of regeneration }
\end{aligned}
$$

The first phase of this work was concentrated on what occurs in the regeneration reactor. The objectives were to predict the effec:s of experimental variations and to use these results to guide further experimental efforts.

\section{Model Description}

A flow chart for the regeneration process model is given in Fig. 18. The Input parameters consist of (1) reactor conditions and size (temperature, pressure, fluidizing gas velocity, fluldized bed depth, and reactor diameter), (2) feed stream description (feed fluidizing gas temperature, sulfated sorbent feed rate, sorbent composition, $i . e$. , sulfur and carbonate, and feed sorbent temperature), and (3) coal properties (composition, i.e., carbon, hydrogen, and sulfur and heating value). The conversions in the model (extent of 


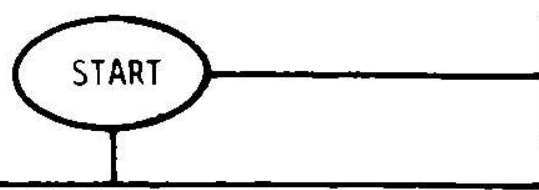

\section{INPUT PARAMETERS}

CALCULATE:

1) SOLID RESIOENCE TIME, I

2) EXTENT OF REGENERATION, $R=f(r, t)$

3) INPUT GAS RATE

4) HEAT OF REACTIONS

5) HEAT LOSSES

6) SENSIBLE HEATS FOR SOLID AND GAS STREAMS

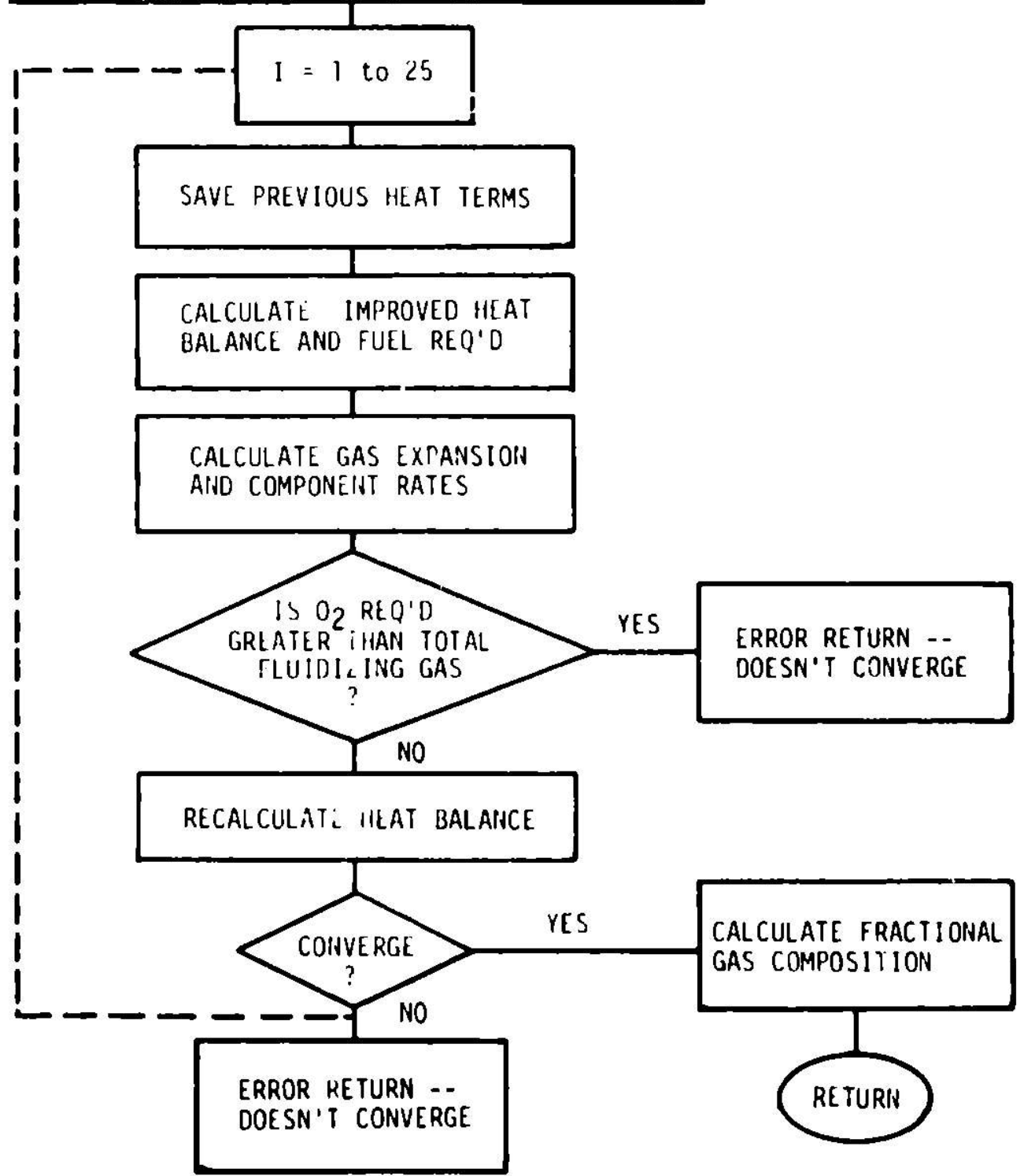

Fig. 18. Flow diagram for the regeneration process model 
regeneration) are predicted from the above given (Section II) least squares best fit equatio, Eq. 9, which was obtained from the experimental data in Table 1 .

$$
\ln (1-R)=A \cdot \tau+B \cdot \tau^{2}
$$

where $\mathrm{R}=$ fractional extent of $\mathrm{CaO}$ regeneration ( $i . e$. , at complete regeneration, $R=1$ )

$\tau=$ particle residence time in the reactor, min

$$
\begin{aligned}
& A \times 10^{2}=-5.05-8.72 \mathrm{~T}-4.00 \mathrm{~T}^{2} \\
& \text { B } \times 10^{4}=-2.94+18.64 \mathrm{~T}+10.65 \mathrm{~T}^{2} \\
& \mathrm{~T}=(\mathrm{t}-1050) / 50
\end{aligned}
$$

where $t=$ regeneration temperature, ${ }^{\circ} \mathrm{C}$

Equation 9 was found to be a good mathematical model of the dependence of the extent of $\mathrm{CaO}$ regeneration on regeneration temperature and solids residence time in the reactor for the investigated experimental range.

The decomposition reactions that the sorbent undergoes are the calcination reaction:

$$
\mathrm{CaCO}_{3}(\mathrm{~s})+\mathrm{CaO}(\mathrm{s})+\mathrm{CO}_{2}
$$

and the reductive decomposition reactions (Eq. 1 and 2). All of these decomposition reactions are endothermic and their thermal requirements are provided by the coal $\left(\mathrm{CH}_{\mathrm{m}}+\mathrm{nH}_{2} \mathrm{O}\right)$ combustion reactions which are represented as follows in the model. For oxidizing conditions:

$$
\left(\mathrm{CH}_{\mathrm{m}}+\mathrm{nH}_{2} \mathrm{O}\right)(\mathrm{s})+\left(\frac{\mathrm{m}}{4}+1\right) \mathrm{O}_{2}+\mathrm{CO}_{2}\left(\frac{\mathrm{m}}{2}+\mathrm{n}\right) \mathrm{H}_{2} \mathrm{O}
$$

for reducing conditions:

$$
\left(\mathrm{CH}_{\mathrm{m}}+\mathrm{nH}_{2} \mathrm{O}\right)(\mathrm{s})+1 / 2 \mathrm{O}_{2}+\mathrm{CO}+\frac{\mathrm{m}}{2} \mathrm{H}_{2}+\mathrm{nH}_{2} \mathrm{O}
$$

From the above decomposition and combustion reactions, it is apparent that the gas volume increases as a result of reactions in the reactor.

In the model, the energy balance is performed by assuming that (1) the feed streams are first cooled to $25^{\circ} \mathrm{C}$, (2) the feed streams ars then reacted, and (3) the product solid and gas streams are heated to the operating reactor temperature. The sensible heats of the streams are based on the rates and compositions of the streams.

The total heat requirement $(Q)$ in the regenerator reactor is:

$$
Q=Q_{\text {lost }}+Q_{\text {des }}+Q_{\text {cal }}+Q_{\text {sorb }}+Q_{\text {gas }}+Q_{\text {ec }}
$$


where

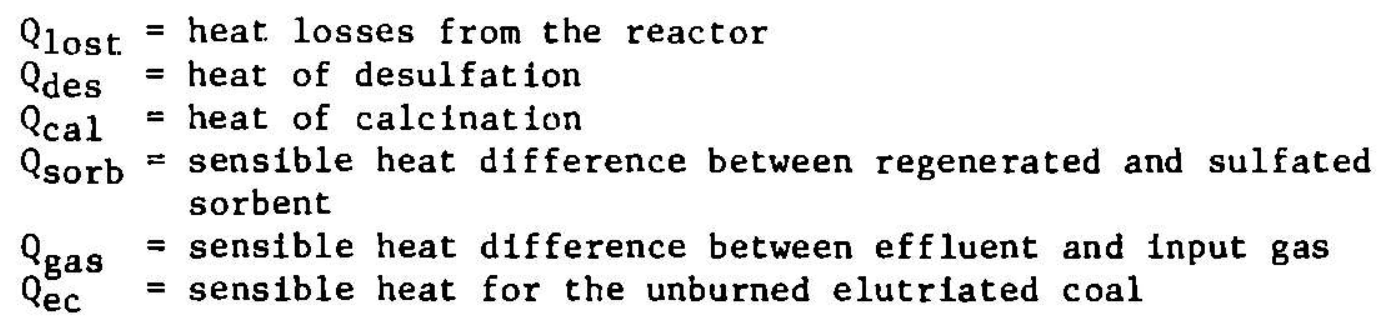

It is assumed that this internal heat requirement w111 be satisfied by the combustion of coal.

$$
Q=Q_{c 1}+Q_{c c}
$$

where

$Q_{c 1}=$ heat 11berated during the required incomplete combustion of coal

If $Q_{c i}<Q$,

$Q_{c c}=$ additional heat requirements to be supplied by complete combustion of coal (Eq. 15)

If $Q_{c 1}>Q$,

$Q_{c c}=$ heat which must be removed from the process

The major assumptions and properties of the model are summarized below:

1. The solids and the of $f$-gas exit at the reactor temperature.

2 . The sorbent is fully calcined during regeneration.

3. The extent of regeneration is a function of solids residence time and temperature (Eq. 9).

4. The heat capacitles of solid and gas constituents are temperature-dependent.

5. Oxygen concentration in the feed gas can be varled.

6. Total coal utilization 1 s $80 \%$ (experimental average).

Using the stated assumptions, the above mass and energy relations are interlocked and solved for different conditions, as shown in the flow diagran: for the model (Fig. 18).

Examples of plotted calculated output and comparisons with some exper1mental results are given in Figs. 19 through 23, to which the following operating conditions apply:

Temperature: $1094^{\circ} \mathrm{C}\left(2000^{\circ} \mathrm{F}\right)$

Fluidizing-gas velocity: $1.07 \mathrm{~m} / \mathrm{sec}(3.5 \mathrm{ft} / \mathrm{sec})$

Pressure: $153 \mathrm{kPa}$ (22.5 psia)

Reactor ID: $10.8 \mathrm{~cm}(4.25 \mathrm{in}$. 
Nominal fluldized-bed helght: $46 \mathrm{~cm}$ (19 1n.)

Feed gas temp: $344^{\circ} \mathrm{C}\left(650^{\circ} \mathrm{F}\right)$

Feed solids temp: $25^{\circ} \mathrm{C}\left(77^{\circ} \mathrm{F}\right)$

Solids residence time: $2-200 \mathrm{~min}$ (mass feed rates:

$90-0.9 \mathrm{~kg} / \mathrm{hr}$ )

Sulfated Tymochtee dolomite: $9.5 \%$ sulfur and $9.5 \% \mathrm{CO}_{3}{ }^{2-}$

Predicted Effect's of Sollds Residence Time on Volumetric Gas Change. The input functional dependence of extent of $\mathrm{CaO}$ regeneration (Eq. 9) is regiven in Fig. 19, along with the calculated increase in gas volume during regeneration, as a function of solids residence time (SRT). At SRTs of less than $10 \mathrm{mln}$, large gas volumetric Increases are predicted, caused by necessarily increased cu.l combustion due to (1) increased heat requirements (sensible heat diffe:ences of solids and gases, and heat of decomposition reactions) and (2) increased solids decomposition for the process. The increases in gas volume dilute the $\mathrm{SO}_{2}$ in the effluent gas.

Coal Feed Rate and Oxygen Concentration. In Fig. 20, the predicted coal feed rate and the predicted required oxygen concentration are given as functions of SRT. The experimental conditions and results for the measured vartables in experiments CS-11 and -12 are also plotted for comparison with the predictions. Agreement of predicted values with experimentally obtained values was good.

Off-Gas Composition. The predicted off-gas constituent concentrations as functions of solids residence time are given in Fig. 21. The concentrations of all pertinent constituents increase with decreasing SRT (increasing solids feed rate). At a SRT of $5 \mathrm{~min}$, a SO $\mathrm{SO}_{2}$ concentration of $9.4 \%$ in the dry off-gas is predicted for the experimental conditions described above.

Heat Requirements. The predicted individual heat requirements for the one-step regeneration process are plotted in Fig. 22 as functions of solids residence time. At low SRT, the sensible heat requirements of the solids and gas constitute most of the required heat.

Cost for Regeneration Fuel. The fuel cost for regeneration per electric power unit produced when burning $3 \%$ sulfur coal has been predicted as a function of SRT and is shown in F1g. 23. The experimental conditions for regeneration are given above. The costs plotted are relative costs obtained to estimate the effect of operating conditions such as SRT and feed solid and gas temperatures. In an industrlal process, these costs would be lowered by recovering the sensible heat from the effluent regenerator streams. (A) coal cost of $\$ 29 /$ tonne was used in predicting the regeneration fuel costs.) It has been found that for the experimental conditions outlined above, the energy cost of regeneration 18 opt1mum at a SRT of $29 \mathrm{~min}$. (For an industrial process, it 18 expected that the opt 1mimum will occur at a lower solid residence $t$ ime.) At lower solids residence $t$ imes, the extent of regeneraticn decreases, and the sensible heat requirements for the solids and gas increase rapidly for these conditions (cold solids and gas feed).

Preliminary Sensitivity Analysis on Selected Process Design Conditions

Table 4 shows, for a solids residence time of $5 \mathrm{~min}$, the predicted 


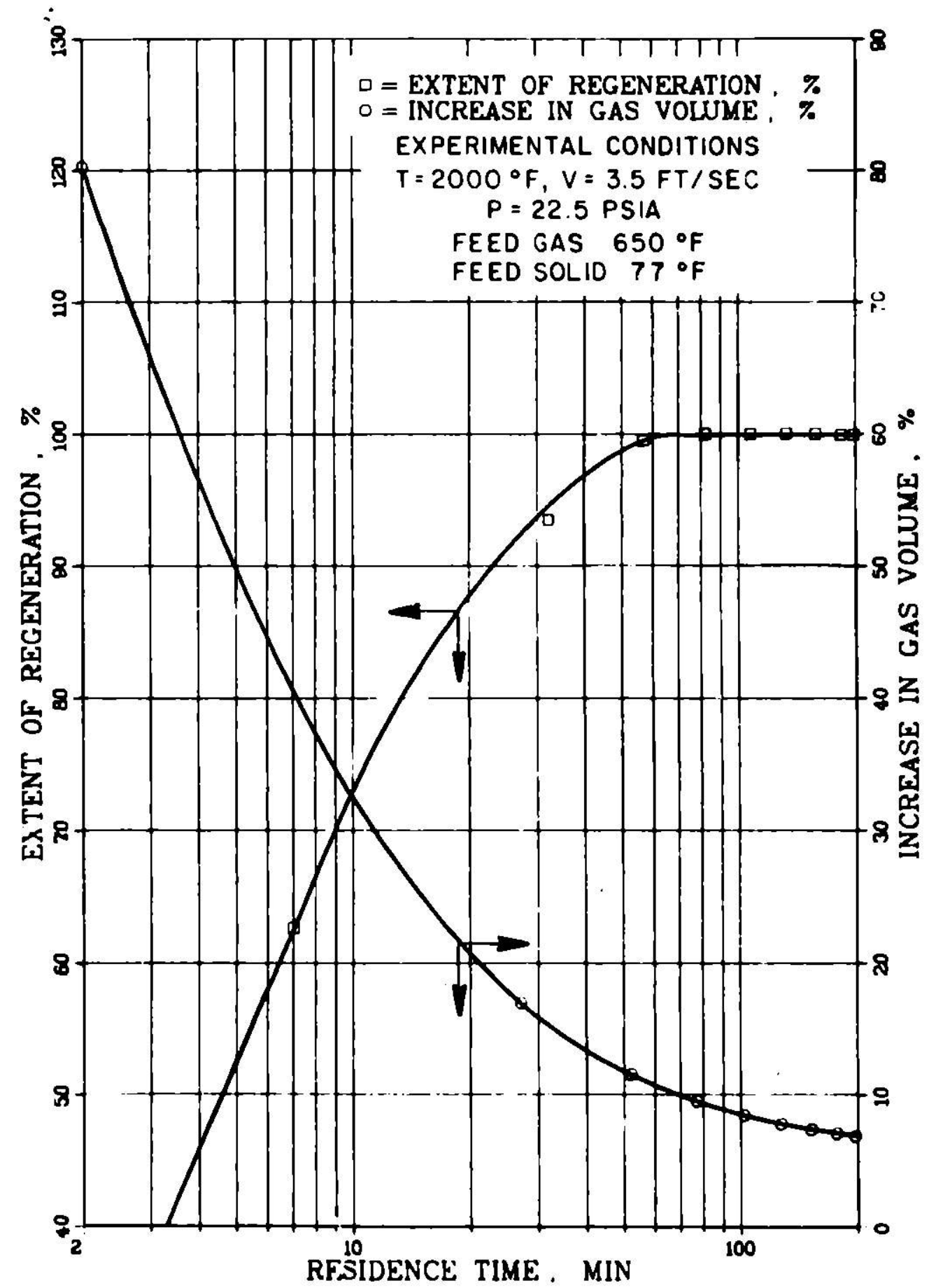

P1g. 19. Experimental solids regeneration and predicted increase in gas volume during regeneration as functions of solids residence time 


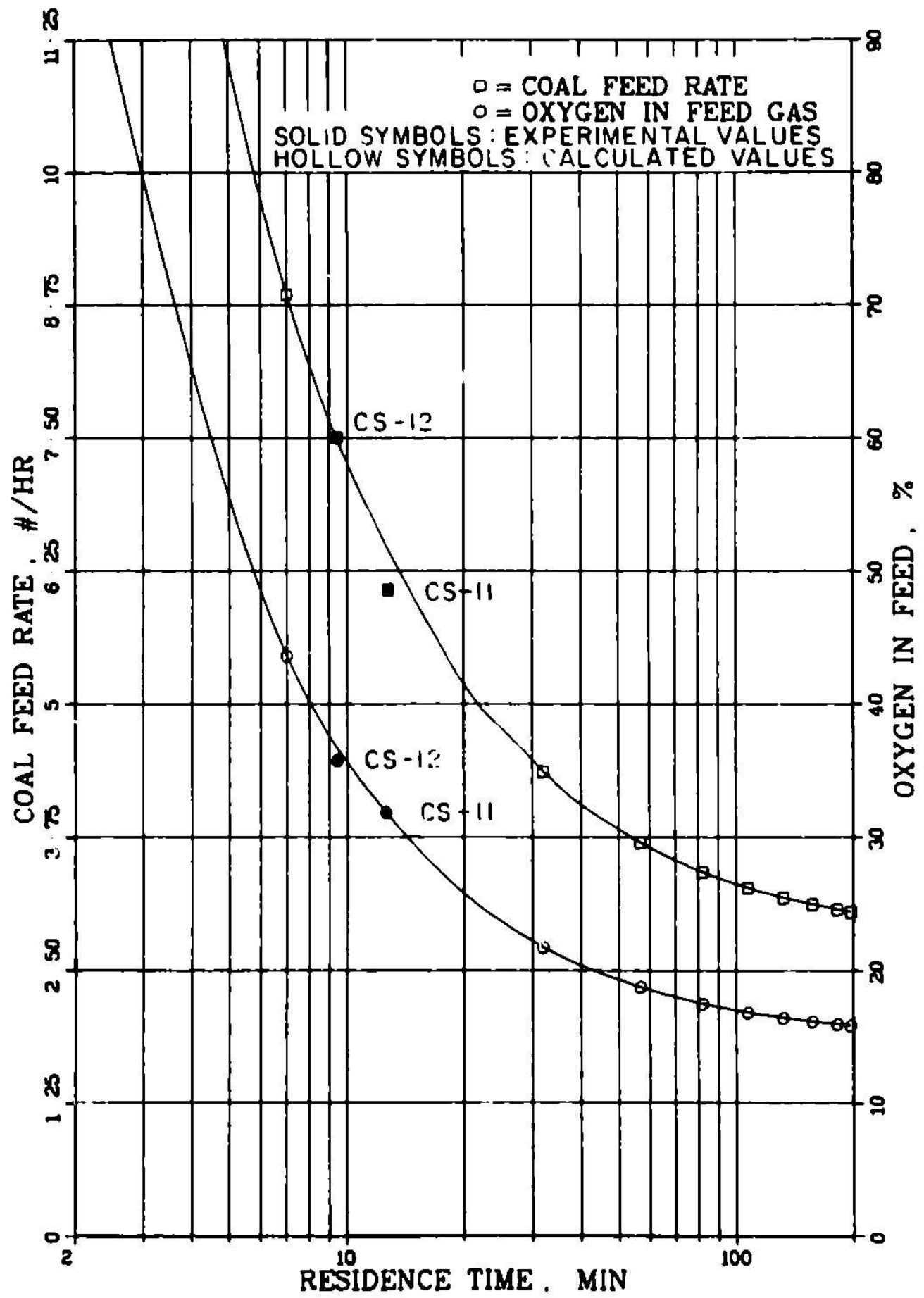

Fig. 20. Predicted and experimental required coal feed rate and oxygen concentration in the feed gas as functions of solids residence time 


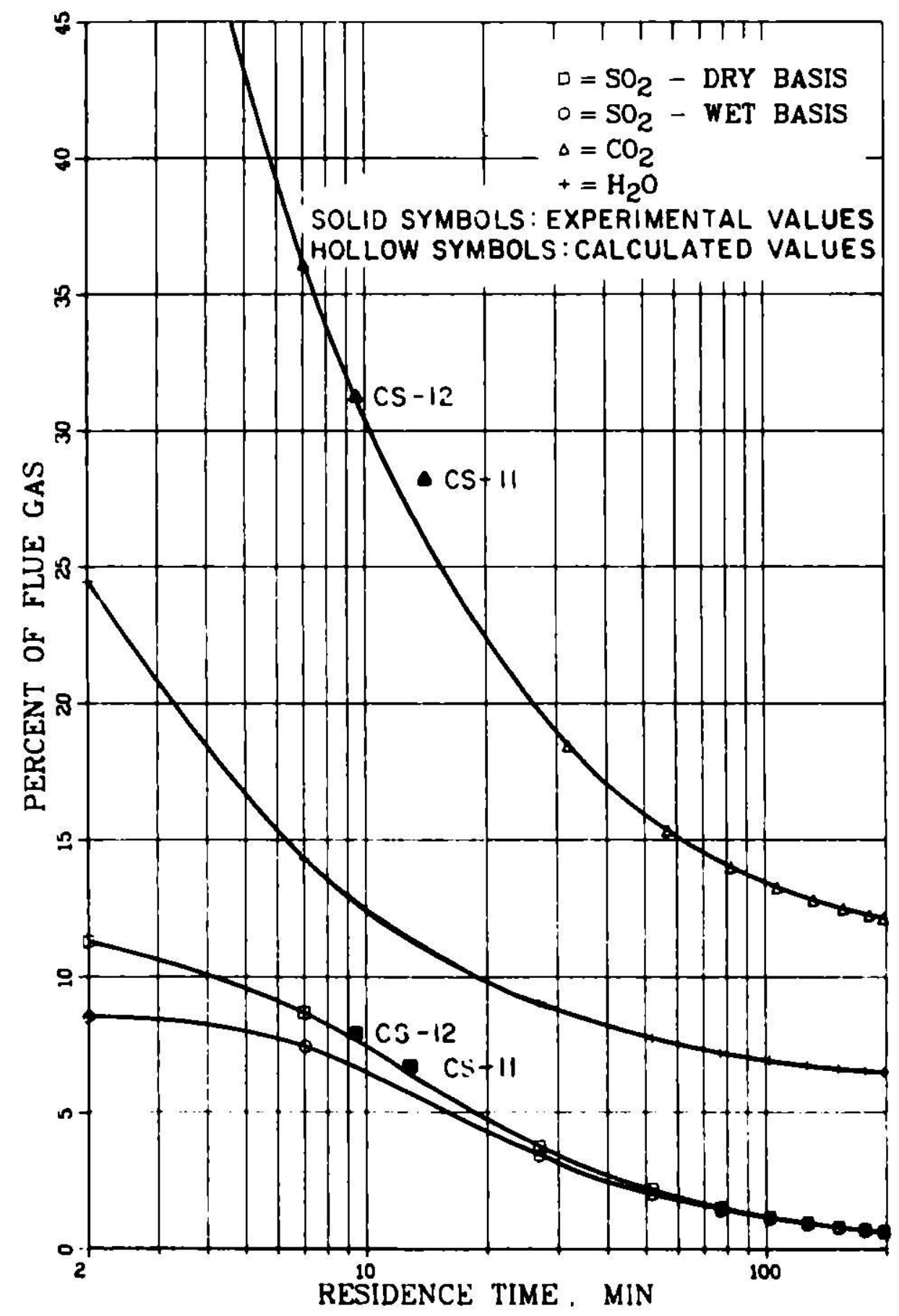

Fig. 21. Predicted off-gas constituent concentrations as functions of solids residence time 


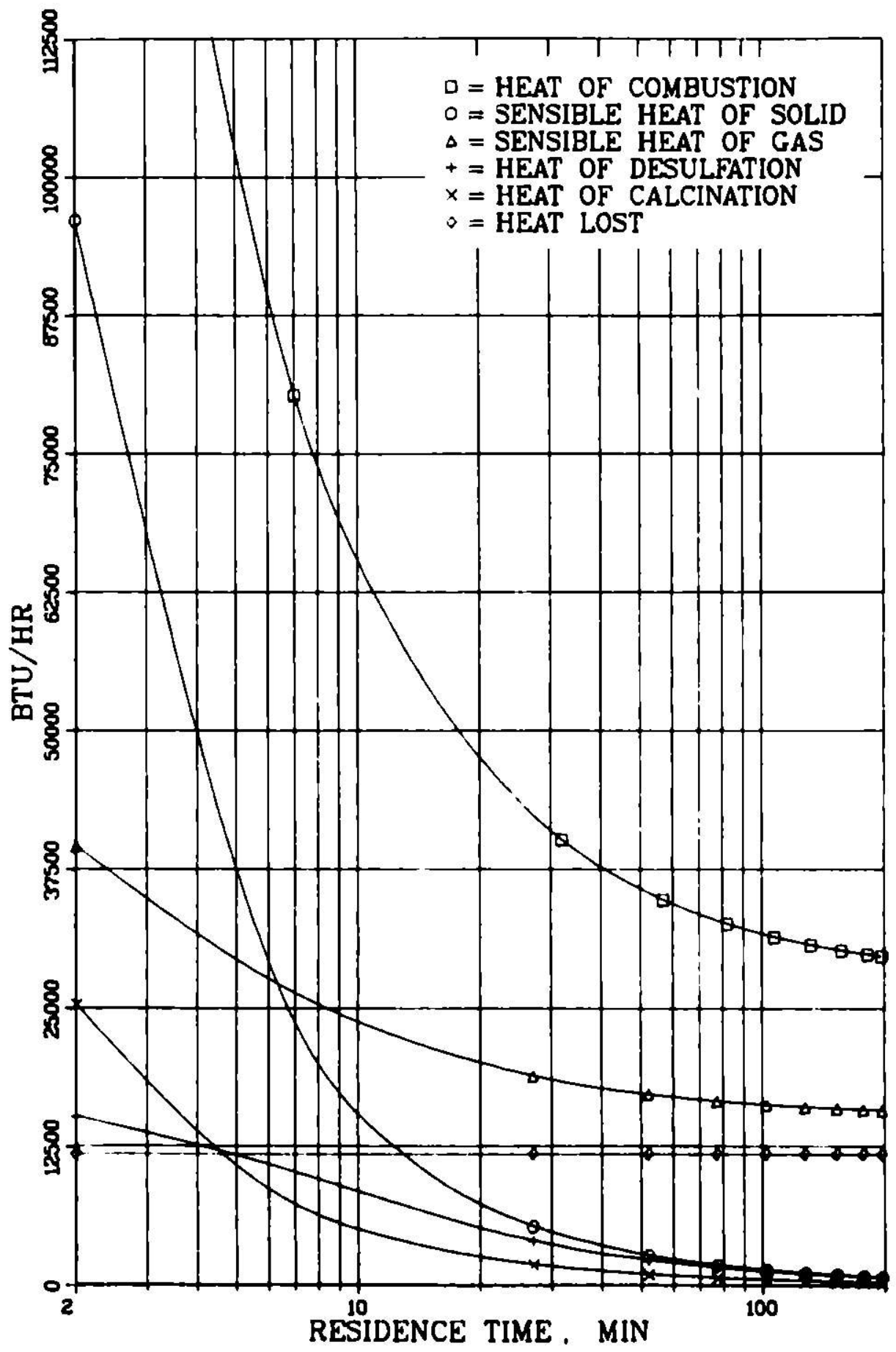

Fig. 22. Predicted individual heat requirements as a function of solids residence $t$ ime 


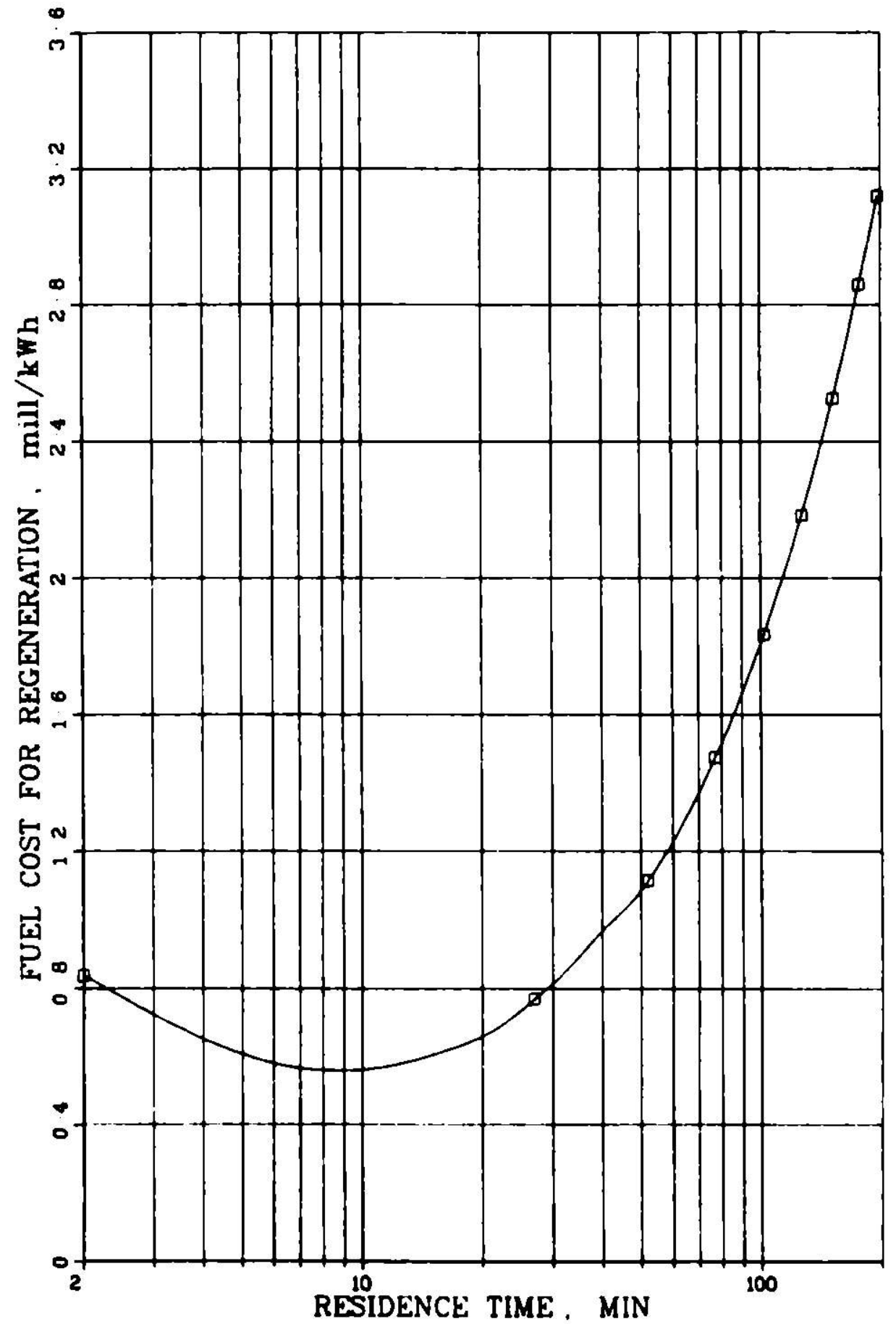

F18. 23. Predicted fuel cost for regeneration per electric power unit produced when burning $3 \%$ sulfur coal as a function of solids residence time. (These costs are not representative of those in a commercial plant sincc conditions have not been optimized.) 
Table 8. Predicted effects of design conditions on regeneration results.

Sulfated Sorbent: Tymochtee Dolomite ( 9.5 wt $\% \mathrm{~S}$ )

Regeneration Temperature: $1094^{\circ} \mathrm{C}$

Sollds Residence Time: $5 \mathrm{~min}$

Fluidizing Velocity: $1.07 \mathrm{~m} / \mathrm{sec}$

\begin{tabular}{|c|c|c|c|c|c|c|c|c|c|c|c|}
\hline & \multicolumn{5}{|c|}{ Design Conditions } & \multicolumn{6}{|c|}{ Predicted Results } \\
\hline & $\begin{array}{l}\text { Pressure, } \\
\text { kPa }\end{array}$ & $\begin{array}{l}\text { Sollds } \\
\text { Feed } \\
\text { Temp, } \\
{ }^{\circ} \mathrm{C}\end{array}$ & $\begin{array}{l}\text { Gas } \\
\text { Feed } \\
\text { Temp, } \\
{ }^{\circ} \mathrm{C}\end{array}$ & $\begin{array}{l}\text { Carbonate } \\
\text { in Sulfated } \\
\text { Sorbent, } \\
\text { i }\end{array}$ & $\begin{array}{l}\text { Reactor } \\
\text { Dla, } \\
\mathrm{cm}\end{array}$ & $\begin{array}{c}\mathrm{SO}_{2} \text { In Dry } \\
\text { of f-Gas, } \\
\%\end{array}$ & $\begin{array}{l}\text { Req. } \\
\text { Feed } \\
\mathrm{O}_{2} \\
\mathrm{z}\end{array}$ & $\begin{array}{c}\text { Gas } \\
\text { Volume } \\
\text { Increase, } \\
\%\end{array}$ & $\begin{array}{l}\text { Process Heat } \\
\text { RequIrement, } \\
\text { Etu/hr }\end{array}$ & $\begin{array}{l}\text { Fuel Cost for } \\
\text { Regeneration } \\
\text { milis } / \mathrm{kWh}\end{array}$ & $\begin{array}{l}\text { Tonnes of Coal } \\
\text { for Regeneration/ } \\
\text { Tonne of Coal for } \\
\text { Combustion }\end{array}$ \\
\hline 1 & 153 & 25 & 345 & 9.5 & 10.8 & 9.6 & 53.5 & 49.4 & $89 \mathrm{~K}$ & 0.59 & 0.068 \\
\hline 2 & 153 & 650 & 650 & 9.5 & 10.8 & 9.4 & 38.6 & 46.1 & $62 \mathrm{~K}$ & 0.45 & 0.052 \\
\hline 3 & 153 & 650 & 650 & 9.5 & 21.6 & 9.3 & 34.9 & $\div 5.2$ & $220 \mathrm{~K}$ & 0.41 & 0.048 \\
\hline 4 & 153 & 650 & 650 & 9.5 & 43.2 & 9.3 & 33.6 & 44.9 & $841 \mathrm{~K}$ & 0.40 & 0.046 \\
\hline 5 & 153 & 650 & 650 & 0 & 10.8 & 10.3 & 33.3 & 32.5 & $52 \mathrm{~K}$ & 0.40 & 0.046 \\
\hline 6 & 102 & 650 & 650 & 9.5 & 10.8 & 12.7 & 54.6 & 67.4 & $58 \mathrm{~K}$ & 0.43 & 0.049 \\
\hline 7 & 153 & 870 & 870 & 9.5 & 10.8 & 9.3 & 32.0 & 44.5 & $50 \mathrm{~K}$ & 0.39 & 0.045 \\
\hline 8 & 153 & 1094 & 870 & 9.5 & 10.8 & 9.2 & 26.0 & 43.2 & $39 \mathrm{~K}$ & 0.33 & 0.038 \\
\hline 9 & 153 & 870 & 1094 & 9.5 & 10.8 & 9.3 & $31 . n$ & 44.3 & $48 \mathrm{~K}$ & 0.38 & 0.043 \\
\hline 10 & 153 & 1094 & 1094 & 9.5 & 10.8 & 9.2 & 25.0 & 42.9 & $37 \mathrm{~K}$ & 0.32 & 0.037 \\
\hline
\end{tabular}

ahese costs are not representative of those in a commercial plant since conditions have not been optimized and no credit for recoverable sensible heat is given. Coal cost, $529 /$ tonne.

b 3 ut 2 coal was assumed to be burned in the combustion step. 
effects of solids and gas feed temperatures, fluid hed temperature, fluidizing gas velocity, experimental pressure, carbonate concentration, and reactor diameter on: $\mathrm{SO}_{2}$ concentration in the off-gas, oxygen requirement in the feed, increase in gas volume, process heat requirement, fuel consumption, and fuel cost for regeneration. Case 1 represents the input conditions for the experimental capabilities of the existing (process development-scale) experimental regeneration system. The piedicted $\mathrm{SO}_{2}$ concentrations as a function of solids residence time and temperature are given in Fig. 16 for the experimental conditions of Case 1.

In Cases 2, 3, and 4, the effects of increasing the reactor ID from $10.8 \mathrm{~cm}$ to $43.2 \mathrm{~cm}$ were predicted. For the two 1 arger reactors, the heat losses are lower and thus the energy cost of regeneration is reduced. The $\mathrm{SO}_{2}$ concentration in the dry off-gas is predicted to be unaffected by this fourfold increase in dfameter.

The effect of carbonate content in the sulfated sorbent was predicted by comparing Cases 2 and 5 . Decreasing the concentration of $\mathrm{CO}_{3}{ }^{2}-$ from $9.5 \%$ to 0 would result in increasing the $\mathrm{SO}_{2}$ concentration in the dry of $f$-gas from $9.4 \%$ to $10.3 \%$.

The most effective parameter for Influencing the $\mathrm{SO}_{2}$ concentration in the dry off-gas was found to be experimental pressure. Decreasing the pressure from $153 \mathrm{kPa}(22.5 \mathrm{psia})$ In Case 2 to $102 \mathrm{kPa}$ (15 psia) in Case 6, the $\mathrm{SO}_{2}$ concentration in the off-gas would increase from $9.4 \%$ to $12.7 \%$ because the total gas feed rate would decrease by $\sim 50 \%$.

In Cases $2,7,8,9$, and 10 , the effects of preheating the feed solids and gas to temperatures as high as $1094^{\circ} \mathrm{C}\left(2000^{\circ} \mathrm{F}\right)$ are predicted for a solids residence $t$ ime of $5 \mathrm{~min}$. The $\mathrm{SO}_{2}$ concentration in the wet effluent gas (not shown) is predicted to increase from 8.1 in Case 1 ( $16 \%$ water) to $8.3 \%$ in Case 10 ( $9.1 \%$ water). However, the $\mathrm{SO}_{2}$ concentration in the dry off-gas is predicted not to increase because the amount nf water formed decreased. The required oxygen concentration in the feed gas decreased from $53.5 \%$ in Case 1 to $31 \%$ in Case 9 . The possible effect of preheating the sulfated sorbent on the rate of regeneration was not considered. These predictions suggest that for a realistic plant situation in which air would be utflized rather than oxygen-enriched gas, a fluldizing gas veloc 1 ty greater than $1.07 \mathrm{~m} / \mathrm{s}$ will be required to satisfy the oxygen requirements of the system at the same solids residence $t$ ime of $5 \mathrm{~min}$.

The energy cost of regeneration (per unit of electric power generated with the combustion of $3 \%$ sulfur coal) decreased from $0.6 \mathrm{mi11} / \mathrm{kWh}$ (Case 1 ) to $0.3 \mathrm{mill} / \mathrm{kWh}$ (Case 10). In terms of relative amounts of coal required for regeneration compared to that required for power generation, regeneration coal requireme its decreased from $7 \%$ (Case 1) to $4 \%$ (Case 10). It was assumed that no energy was recovered from the hot $\left(1095^{\circ} \mathrm{C}\right)$ solids and gas effluent streams. It is expected that with proper energy credits, the regeneration reactor w111 Impose an energy burden $c t 2-3 \%$ on the power plant. 


\section{CONCLUSIONS}

From a technical standpoint, the fluidized-bed sorbent regeneration process using coal as the fuel has been found to be a promising process for reducing the potentially large waste disposal problem from fluldized-bed coal combustion processes. Ongoing economic evaluations at ANL will determine its economic feasibility.

\section{ACKNOWLEDGMENTS}

The support of this program by the Energy Research and Development Administration and the Environmental Protection Agency is gratefully acknowledged. This study was made under the direction of Messrs. A. A. Jonke, D. Webster, and L. Burris of the Chemical Engineering Division. Experimental data were obtained by Messrs. R. Mowry, C. Schoffstoll, and J. Stockbar.

\section{REFERENCES}

1. W. F. Blschoff, Jr., and Peter Stelner, "Coal Converts $\mathrm{SO}_{2}$ to $\mathrm{S}, "$ Chem. Eng., 74 (January 1975).

2. D. L. Keairns et al., "Fluidized Bed Combustion Process Evaluation, Phase II - Pressurized Fluidized Bed Coal Combustion Development, EPA-650/2-75-027-C (September 1975).

3. D. A. Martin, F. E. Brantley, and D. M. Yergensen, "Decomposttion of Gypsum in a Fluidized Bed Reactor," U.S. Bureau of Mines Report of

- Invest1gation 6286 (1963).

4. M. Hartman and R. W. Coughlin, "Reactions of Sulfur Dioxide with Limestone and the Influence of Pore Structure," Ind. Eng. Chem. 13(3), 248 (1974).

5. A. Skopp, J. T. Sears, and R. R. Bertrant, "Fluld Bed Studies of the Limestone Based Flue Gas Desulfuri::ation Process," Report No. GR-9-FGS-69, Esso Research and Engineering Company, Government Research Div., Linden, N. J.

6. G. J. Vogel et al., "Reduction of A mospheric Pollution by the Application of Fluidized Bed Combustion and Regeneration of Sulfur-Containing Additives," Annual Report, July 1971 - June 1972, ANL/ES-CEN-1005 and EPA-R2-73-253.

7. W. M. Swift and T. D. Wheelock, "Decomposition of Calclum Sulfate in a Two-Zorie Reactor," Ind. Eng. Chem. Process Design Develop., 14(3) 323 (1975).

8. R. C. Hoke et al., "A Regenerative Limestone Process for Fluldized Bed Cosl Combustion and Desulfurization," EPA-650/2-.74-001 (January 1974). 
9. T. D. Wheelock and D. R. Boylan, "Reductive Decomposition of Gypsum by Carbon Monoxide," Ind. Eng. Chem. 52 215 (March 1960).

10. J. S. Gordon et al., "Study of the Characterization and Control of Air Pollution from a Flutdized-Bed Boller - the $\mathrm{SO}_{2}$ Acceptor Process " Pope, Evans and Robbins report, EPA-R2-72-021. (1972). 